\title{
Therapy Prospects for Mitochondrial DNA Maintenance Disorders
}

\author{
Javier Ramón 1,2 ${ }^{\mathbb{D}}$, Ferran Vila-Julià 1,2, David Molina-Granada 1,2 ${ }^{1}$, Miguel Molina-Berenguer 1,2 $\mathbb{D}$, \\ Maria Jesús Melià ${ }^{1,2}\left(\mathbb{D}\right.$, Elena García-Arumí ${ }^{1,2}\left(\mathbb{D}\right.$, Javier Torres-Torronteras ${ }^{1,2}\left(\mathbb{D}\right.$, Yolanda Cámara ${ }^{1,2}(\mathbb{D})$ and \\ Ramon Martí ${ }^{1,2, *(\mathbb{D})}$
}

1 Research Group on Neuromuscular and Mitochondrial Diseases, Vall d'Hebron Research Institute, Universitat Autònoma de Barcelona, 08035 Barcelona, Spain; javier.ramon@vhir.org (J.R.); ferran.vila@vhir.org (F.V.-J.); david.molina@vhir.org (D.M.-G.); miguel.molina@vhir.org (M.M.-B.); maria.jesus.melia@vhir.org (M.J.M.); elena.garcia@vhir.org (E.G.-A.); javier.torres@vhir.org (J.T.-T.); yolanda.camara@vhir.org (Y.C.)

2 Biomedical Network Research Centre on Rare Diseases (CIBERER), Instituto de Salud Carlos III, 28029 Madrid, Spain

* Correspondence: ramon.marti@vhir.org

\section{check for} updates

Citation: Ramón, J.; Vila-Julià, F.; Molina-Granada, D.;

Molina-Berenguer, M.; Melià, M.J.; García-Arumí, E.; Torres-Torronteras,

J.; Cámara, Y.; Martí, R. Therapy

Prospects for Mitochondrial DNA

Maintenance Disorders. Int. J. Mol.

Sci. 2021, 22, 6447. https://

doi.org/10.3390/ijms22126447

Academic Editor: María

Eugenia Soriano

Received: 22 May 2021

Accepted: 11 June 2021

Published: 16 June 2021

Publisher's Note: MDPI stays neutral with regard to jurisdictional claims in published maps and institutional affiliations.

Copyright: (c) 2021 by the authors. Licensee MDPI, Basel, Switzerland. This article is an open access article distributed under the terms and conditions of the Creative Commons Attribution (CC BY) license (https:// creativecommons.org/licenses/by/ $4.0 /)$.

\begin{abstract}
Mitochondrial DNA depletion and multiple deletions syndromes (MDDS) constitute a group of mitochondrial diseases defined by dysfunctional mitochondrial DNA (mtDNA) replication and maintenance. As is the case for many other mitochondrial diseases, the options for the treatment of these disorders are rather limited today. Some aggressive treatments such as liver transplantation or allogeneic stem cell transplantation are among the few available options for patients with some forms of MDDS. However, in recent years, significant advances in our knowledge of the biochemical pathomechanisms accounting for dysfunctional mtDNA replication have been achieved, which has opened new prospects for the treatment of these often fatal diseases. Current strategies under investigation to treat MDDS range from small molecule substrate enhancement approaches to more complex treatments, such as lentiviral or adenoassociated vector-mediated gene therapy. Some of these experimental therapies have already reached the clinical phase with very promising results, however, they are hampered by the fact that these are all rare disorders and so the patient recruitment potential for clinical trials is very limited.
\end{abstract}

Keywords: mitochondria; mtDNA; replication; depletion; multiple deletions; therapy; nucleoside; gene therapy

\section{Mitochondria and Mitochondrial Diseases}

Mitochondria are organelles located in the cytoplasm of most eukaryotic cells and are involved in many important cellular metabolic processes, among which the synthesis of ATP has been classically considered their main function [1]. Mitochondria also play other important cellular roles such in the maintenance of calcium homeostasis, regulation of apoptosis, lipid metabolism and the synthesis of hormones, vitamins and the heme group [2-5].

The mitochondrial pathway leading to ATP synthesis is known as oxidative phosphorylation (OXPHOS), and it is mediated by the transformation of the energy contained in the reduced substrates $\mathrm{NADH}$ and $\mathrm{FADH}_{2}$ into electrochemical energy which is finally used to phosphorylate ADP to ATP, the main energy currency in the cell. Electrons from these reduced compounds flow through different substrates by the catalysis of four complexes (I-IV) of the electron transport chain (ETC). This flow is coupled to the pumping of protons from the mitochondrial matrix to the intermembrane space, creating a proton electrochemical gradient across the mitochondrial inner membrane that finally drives the phosphorylation of ADP to ATP through the catalysis of the ATP synthase, the fifth complex of the OXPHOS system [1].

The endosymbiont hypothesis postulates that mitochondria and plastids originated from prokaryotic progenitors associated with ancestor hosts to generate the first eukaryotic 
cells [6], and this theory is widely accepted [7]. Owing to their origin, mitochondria have their own genome consisting of a variable copy number of a circular double-stranded molecule of DNA. In humans, mitochondrial DNA (mtDNA) is $16.5 \mathrm{~kb}$ and contains 27 genes encoding 13 proteins of the OXPHOS system, as well as 22 tRNAs and 2 rRNAs used for the translation of these proteins, which takes place within the mitochondria [1]. Every cell contains several mitochondria and every mitochondrion in turn contains several copies of mtDNA. The amount of mitochondria and the mtDNA copy number depends on the tissue and its specific energy demands [8].

As indicated above, 13 subunits of the mitochondrial OXPHOS system (belonging to complexes I, III, IV and V) are encoded by mtDNA. All other subunits of the five OXPHOS complexes, as well as all other proteins located within mitochondria and needed for their function (more than 1100 proteins) are encoded by the nuclear DNA (nDNA), synthesized in the cytosol and then imported to mitochondria [9]. Therefore, the operations of mitochondria are controlled by two genomes: nDNA and mtDNA, a fact that determines many aspects of the mitochondrial function and the characteristics of different mitochondrial disorders.

Although mitochondria have several functions, the term "mitochondrial disease" classically refers to those diseases caused by dysfunctional OXPHOS which results in insufficient ATP synthesis in affected tissues [5]. This encompasses a group of diseases with heterogeneous clinical presentation and genetic origin caused by mutations in either mtDNA or nDNA. The most affected tissues are the most energy demanding ones: muscle, central nervous system, endocrine system, liver and kidney [10]. The inheritance pattern of mitochondrial diseases can be autosomal dominant or recessive, $\mathrm{X}$-linked (for those caused by mutations in nuclear genes) or maternal (for those caused by mutations in mtDNA) [5]. When the mtDNA mutation is located in one of the 13 genes encoding subunits of the OXPHOS system, the consequence is usually an isolated deficiency of the affected complex (in some cases, the molecular defect in one complex alters the correct assembly of other ETC components, thus affecting more than one complex). By contrast, when the mutation affects genes encoding one of the 22 tRNAs or the two rRNAs, the translation of the $13 \mathrm{mtDNA}$ encoded subunits is disturbed, leading to a multicomplex defect. In addition, the inheritance and phenotype of the diseases caused by primary mtDNA mutations is determined by the polyplasmic nature of mtDNA [5].

Alternatively, OXPHOS dysfunction can be caused by mutations in nuclear genes encoding subunits of OXPHOS complexes, as well as other factors involved in several processes needed for correct mitochondrial function: factors needed for the ETC complexes assembly, factors regulating mitochondrial protein import, enzymes of the coenzyme Q synthesis pathway, factors involved in mitochondrial translation, maintenance of the mitochondrial lipid milieu or in mitochondrial dynamics, and all factors needed for the correct mtDNA replication and maintenance. Ultimately, mutations in these genes also lead to OXPHOS impairment and therefore to an insufficiency of energy production [11].

\section{Mitochondrial DNA Depletion and Multiple Deletions Syndromes (MDDS)}

Mitochondria contain multiple copies of mtDNA whose integrity and maintenance are critical for the faithful expression of all mtDNA-encoded OXPHOS subunits and correct mitochondrial function. As indicated above, some mitochondrial diseases caused by mutations in nuclear genes affect proteins needed for mtDNA replication and maintenance. When the proteins encoded by these genes do not work properly, dysfunctional mtDNA replication results in quantitative alterations (reduction in mtDNA copy number, i.e., mtDNA depletion) and/or qualitative alterations (multiple deletions in mtDNA and, in some cases, point mutations). For this reason, this specific group of disorders is known as mitochondrial DNA depletion and multiple deletions syndromes (MDDS). These diseases are somehow peculiar because they respond to Mendelian inheritance, but the somatic aberrations (not inherited from the mother) in the mtDNA molecules confer them some 
molecular features typical of primary mtDNA disorders, such as different heteroplasmy degrees in different tissues.

Traditionally, mtDNA maintenance defects have been regarded as two different groups of disorders: mtDNA depletion syndromes, characterized by the reduction in mtDNA copy number in affected tissues, and commonly found in paediatric patients with variable and often severe phenotypes $[12,13]$ and mtDNA multiple deletions syndromes characterized by the presence of this molecular aberration [12]. This second group is often defined by the most common clinical presentation associated with the presence of mtDNA multiple deletions in skeletal muscle (autosomal dominant or recessive progressive externa ophthalmoplegia, $\mathrm{PEO}$ ) and is mainly found in adult patients [14] (https://pubmed.ncbi.nlm.nih.gov/29517884/, accessed on 22 May 2021). However, the knowledge acquired in recent years, as the genetic causes of these disorders are gradually being elucidated, indicates that both mtDNA depletion and multiple deletions may be the result of the same genetic defect and therefore primarily triggered by the same dysfunctional process (although likely at different developmental stages). Most genes associated with depletion in some patients have been found to cause multiple deletions in other patients, even when sharing the same mutation. In some cases, both molecular features may coexist in the same patient [15]. Although the biochemical mechanisms of both molecular alterations should be different, the primary genetic defect is common in many cases. Therefore, we refer to all this group of diseases commonly as MDDS.

The clinical presentation of the different MDDS forms is heterogeneous, even for groups of patients with mutations in the same gene. MDDS are associated with a wide phenotypic spectrum that affects different tissues, ranging from mild forms with presentation in adulthood to severe forms with infantile onset. Moreover, the mutations and phenotypes overlap, which means that alterations in one gene can lead to different phenotypes and similar phenotypes can be caused by mutations in different genes. All these factors make it difficult to associate a clear phenotype to these syndromes in some cases, and therefore to establish their diagnosis and classification.

Table 1 lists the genes whose mutations have been hitherto associated with MDDS. These genes can be classified into four categories according to the biological role of their products which inform us of the pathomechanism accounting for the mtDNA replication defect: (1) proteins belonging to the mtDNA replication machinery; (2) enzymes involved in deoxyribonucleoside triphosphates (dNTP) metabolism; (3) proteins involved in mitochondrial dynamics; and (4) other proteins whose link with mtDNA replication is unknown. In this last group, we find four mitochondrial membrane transporters, as well as other proteins with different functions whose link with mtDNA maintenance is not easily identifiable.

\subsection{Genes Encoding Proteins of the mtDNA Replication Machinery}

mtDNA replication is entirely dependent on nuclear encoded proteins that are synthesized in the cytosol and imported into mitochondria. Interestingly, mutations in genes encoding most of the factors constituting the mtDNA replisome [48,49] have been associated with MDDS (Table 1). Since the first identification of mutations in POLG [16] and TWNK [18] as causative of MDDS in 2001, a total of 10 genes encoding proteins directly involved in mtDNA replication and repair machinery have been incorporated in this list to date, including the recent identification of mutations in LIG3 causing a mitochondrial neurogastrointestinal encephalomyopathy (MNGIE) like phenotype [25]. 
Table 1. Genes associated with mitochondrial DNA replication disorders.

\begin{tabular}{|c|c|c|c|c|c|c|c|c|}
\hline Category & Gene & Protein & $\begin{array}{c}\text { Protein } \\
\text { Function/Pathway }\end{array}$ & Clinical Features & $\begin{array}{l}\text { Type of In- } \\
\text { heritance }\end{array}$ & $\begin{array}{c}\text { Type of } \\
\text { mtDNA } \\
\text { Aberration }\end{array}$ & $\begin{array}{l}\text { OMIM \# } \\
\text { (Gene) }\end{array}$ & $\begin{array}{l}\text { Reference } \\
* \text { (Year) }\end{array}$ \\
\hline \multirow{10}{*}{ 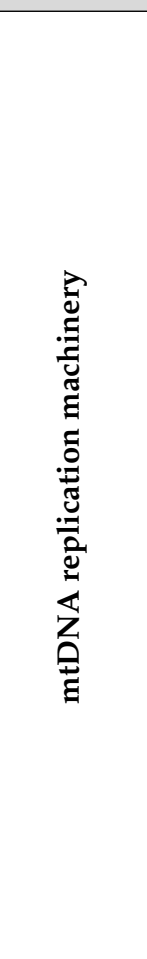 } & POLG & DNA polymerase gamma & Polymerase & Alpers-Huttenlocher syndrome/ataxia/PEO & $\mathrm{AR} / \mathrm{AD}$ & $\mathrm{D} / \mathrm{MD} / \mathrm{PM}$ & 174763 & $\begin{array}{c}{[16]} \\
(2001)\end{array}$ \\
\hline & POLG2 & $\begin{array}{l}\text { DNA polymerase subunit } \\
\text { gamma-2 }\end{array}$ & $\begin{array}{l}\text { Polymerase } \\
\text { (ancillary) }\end{array}$ & $\mathrm{PEO} /$ hepatic failure & $\mathrm{AD} / \mathrm{AR}$ & $\mathrm{MD} / \mathrm{D}$ & 604983 & $\begin{array}{c}{[17]} \\
(2006)\end{array}$ \\
\hline & TWNK & Twinkle & Helicase & $\begin{array}{c}\text { Perrault } \\
\text { syndrome/PEO/ataxia/encephalopathy/IOSCA }\end{array}$ & $\mathrm{AD} / \mathrm{AR}$ & $\mathrm{D} / \mathrm{MD} / \mathrm{PM}$ & 606075 & $\begin{array}{c}{[18]} \\
(2001)\end{array}$ \\
\hline & MGME1 & $\begin{array}{c}\text { Mitochondrial genome } \\
\text { maintenance exonuclease } 1\end{array}$ & Exonuclease & $\mathrm{PEO} /$ emaciation & AR & $\mathrm{D} / \mathrm{MD}$ & 615076 & $\begin{array}{c}{[19]} \\
(2013)\end{array}$ \\
\hline & DNA2 & $\begin{array}{c}\text { DNA replication } \\
\text { ATP-dependent } \\
\text { helicase/nuclease DNA2 }\end{array}$ & Helicase/nuclease & PEO/myopathy/Seckel syndrome & $\mathrm{AD}$ & MD & 601810 & $\begin{array}{c}{[20]} \\
(2013)\end{array}$ \\
\hline & RNASEH1 & Ribonuclease H1 & Ribonuclease & $\mathrm{PEO} /$ muscle weakness/dysphagia/spinocerebellar signs & AR & $\mathrm{D} / \mathrm{MD}$ & 604123 & $\begin{array}{c}{[21]} \\
(2015)\end{array}$ \\
\hline & TFAM & $\begin{array}{l}\text { Mitochondrial transcription } \\
\text { factor A }\end{array}$ & Transcription factor & Neonatal liver failure & $\mathrm{AR}$ & $\mathrm{D}$ & 600438 & $\begin{array}{c}{[22]} \\
(2016) \\
\end{array}$ \\
\hline & TOP3A & DNA topoisomerase 3 alpha & Topoisomerase & PEO/Bloom syndrome-like disorder & $\mathrm{AR}$ & $\mathrm{MD} / \mathrm{D}$ & 601243 & $\begin{array}{c}{[23]} \\
(2018)\end{array}$ \\
\hline & SSBP1 & $\begin{array}{l}\text { Mitochondrial single strand } \\
\text { binding protein }\end{array}$ & ssDNA stabilization & $\begin{array}{l}\text { Optic atrophy/liver failure/neurological syndrome } \\
\text { / retinopathy }\end{array}$ & $\mathrm{AD} / \mathrm{AR}$ & $\mathrm{D}$ & 600439 & $\begin{array}{c}{[24]} \\
(2019)\end{array}$ \\
\hline & LIG3 & Ligase III & $\begin{array}{c}\text { Mitochondrial DNA } \\
\text { ligase }\end{array}$ & MNGIE-like & AR & $\mathrm{D}$ & 600940 & $\begin{array}{c}{[25]} \\
(2021)\end{array}$ \\
\hline
\end{tabular}


Table 1. Cont.

\begin{tabular}{|c|c|c|c|c|c|c|c|c|}
\hline Category & Gene & Protein & $\begin{array}{c}\text { Protein } \\
\text { Function/Pathway }\end{array}$ & Clinical Features & $\begin{array}{l}\text { Type of In- } \\
\text { heritance }\end{array}$ & $\begin{array}{c}\text { Type of } \\
\text { mtDNA } \\
\text { Aberration }\end{array}$ & $\begin{array}{l}\text { OMIM \# } \\
\text { (Gene) }\end{array}$ & $\begin{array}{l}\text { Reference } \\
* \text { (Year) }\end{array}$ \\
\hline \multirow{4}{*}{ 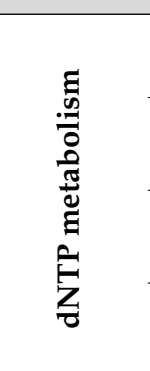 } & TYMP & Thymidine phosphorylase & $\begin{array}{l}\text { Nucleoside } \\
\text { catabolism }\end{array}$ & MNGIE & $\mathrm{AR}$ & $\mathrm{D} / \mathrm{MD} / \mathrm{PM}$ & 603041 & $\begin{array}{c}{[26]} \\
(1999)\end{array}$ \\
\hline & TK2 & Thymidine kinase 2 & dNTP anabolism & Myopathy/PEO & $\mathrm{AR}$ & $\mathrm{D} / \mathrm{MD}$ & 188250 & $\begin{array}{c}27] \\
(2001)\end{array}$ \\
\hline & DGUOK & Deoxyguanosine kinase & dNTP anabolism & Neurohepatopathy/myopathy/PEO & $\mathrm{AR}$ & $\mathrm{D} / \mathrm{MD}$ & 601465 & $\begin{array}{c}{[28]} \\
(2001)\end{array}$ \\
\hline & $R R M 2 B$ & $\begin{array}{c}\text { p53-subunit of } \\
\text { ribonucleotide reductase }\end{array}$ & dNTP anabolism & $\begin{array}{c}\text { Encephalomyopathy/PEO } \\
\text { /MNGIE/KSS/neuropathy/deafness/tubulopathy }\end{array}$ & $\mathrm{AR} / \mathrm{AD}$ & $\mathrm{D} / \mathrm{MD}$ & 604712 & $\begin{array}{c}{[29]} \\
(2007)\end{array}$ \\
\hline \multirow{5}{*}{ 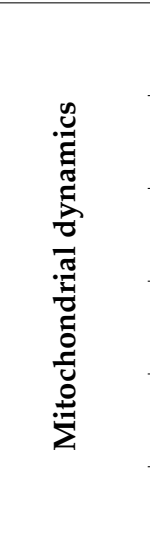 } & OPA1 & $\begin{array}{l}\text { Dynamin-like } 120 \mathrm{kDa} \\
\text { protein, mitochondrial }\end{array}$ & $\begin{array}{l}\text { GTPase/mitochondrial } \\
\text { fusion }\end{array}$ & Optic atrophy/Behr syndrome & $\mathrm{AD}$ & MD & 605290 & $\begin{array}{c}{[30]} \\
(2008)\end{array}$ \\
\hline & MFN2 & Mitofusin-2 & $\begin{array}{l}\text { GTPase/mitochondrial } \\
\text { fusion }\end{array}$ & $\begin{array}{l}\text { Optic atrophy/myopathy/axonal } \\
\text { neuropathy/Charcot-Marie-Tooth }\end{array}$ & $\mathrm{AR} / \mathrm{AD}$ & $\mathrm{D} / \mathrm{MD}$ & 608507 & $\begin{array}{c}{[31]} \\
(2012)\end{array}$ \\
\hline & SPG7 & Paraplegin & $\begin{array}{l}\text { Subunit of m-AAA } \\
\text { protease }\end{array}$ & $\mathrm{PEO} /$ spastic paraplegia & $\mathrm{AR}$ & MD & 602783 & $\begin{array}{c}{[32]} \\
(2014) \\
\end{array}$ \\
\hline & MSTO1 & Protein misato homolog 1 & $\begin{array}{l}\text { Mitochondrial } \\
\text { fusion }\end{array}$ & $\begin{array}{l}\text { Muscular dystrophy with cerebellar } \\
\text { involvement/myopathy/ataxia }\end{array}$ & $\mathrm{AR}$ & $\mathrm{D}$ & 617619 & $\begin{array}{c}{[34]} \\
(2017)\end{array}$ \\
\hline & MICOS13 & $\begin{array}{l}\text { MICOS complex subunit } \\
\text { MIC13 }\end{array}$ & $\begin{array}{l}\text { Maintenance of } \\
\text { cristae structure }\end{array}$ & Hepato-encephalopathy & $\mathrm{AR}$ & $\mathrm{D}$ & 616658 & $\begin{array}{c}{[35]} \\
(2019)\end{array}$ \\
\hline
\end{tabular}


Table 1. Cont.

\begin{tabular}{|c|c|c|c|c|c|c|c|c|c|}
\hline Categ & ory & Gene & Protein & $\begin{array}{c}\text { Protein } \\
\text { Function/Pathway }\end{array}$ & Clinical Features & $\begin{array}{l}\text { Type of In- } \\
\text { heritance }\end{array}$ & $\begin{array}{c}\text { Type of } \\
\text { mtDNA } \\
\text { Aberration }\end{array}$ & $\begin{array}{l}\text { OMIM \# } \\
\text { (Gene) }\end{array}$ & $\begin{array}{l}\text { Reference } \\
* \text { (Year) }\end{array}$ \\
\hline \multirow{12}{*}{ 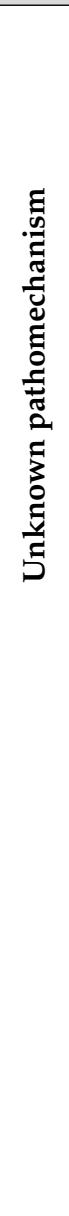 } & \multirow{4}{*}{ 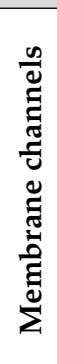 } & SLC25A4 & $\begin{array}{l}\text { Adenine nucleotide } \\
\text { translocator }\end{array}$ & ADP/ATP carrier & PEO/cardiomyopathy/myopathy & $\mathrm{AD} / \mathrm{AR}$ & MD & 103220 & $\begin{array}{l}{[36]} \\
(2000)\end{array}$ \\
\hline & & MPV17 & Protein mpv17 & $\begin{array}{c}\text { Membrane } \\
\text { channel/unknown }\end{array}$ & $\begin{array}{l}\text { Neurohepatopathy/neuropathy/leukoencephalopathy/ } \\
\text { Charcot-Marie-Tooth }\end{array}$ & $\mathrm{AR}$ & $\mathrm{D} / \mathrm{MD}$ & 137960 & $\begin{array}{c}{[37]} \\
(2006)\end{array}$ \\
\hline & & $S L C 25 A 21$ & $\begin{array}{l}\text { Mitochondrial } \\
\text { 2-oxodicarboxylate carrier }\end{array}$ & $\begin{array}{l}\text { Transmembrane } \\
\text { transporter }\end{array}$ & Spinal muscular atrophy-like & $\mathrm{AR}$ & $\mathrm{D}$ & 607571 & $\begin{array}{c}{[38]} \\
(2018)\end{array}$ \\
\hline & & $S L C 25 A 10$ & $\begin{array}{c}\text { Mitochondrial } \\
\text { dicarboxylate carrier }\end{array}$ & $\begin{array}{l}\text { Transmembrane } \\
\text { transporter }\end{array}$ & Epileptic encephalopathy & AR & $\mathrm{D}$ & 606794 & $\begin{array}{c}{[39]} \\
(2018)\end{array}$ \\
\hline & \multirow{8}{*}{ 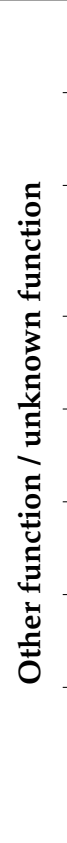 } & SUCLA2 & $\begin{array}{c}\beta \text {-subunit, Succinate-CoA } \\
\text { ligase }\end{array}$ & Krebs cycle & Encephalomyopathy & AR & $\mathrm{D}$ & 603921 & $\begin{array}{l}{[40]} \\
(2005)\end{array}$ \\
\hline & & SUCLG1 & $\begin{array}{l}\alpha \text {-subunit, Succinate-CoA } \\
\text { ligase }\end{array}$ & Krebs cycle & Encephalomyopathy & $\mathrm{AR}$ & $\mathrm{D}$ & 611224 & $\begin{array}{c}{[41]} \\
(2007)\end{array}$ \\
\hline & & $A G K$ & Acylglycerol kinase & Lipid metabolism & $\begin{array}{l}\text { Congenital cataract/hypertrophic } \\
\text { cardiomyopathy/skeletal myopathy and lactic } \\
\text { acidosis/Sengers syndrome }\end{array}$ & $\mathrm{AD}$ & $\mathrm{D}$ & 610345 & $\begin{array}{c}{[42]} \\
(2012)\end{array}$ \\
\hline & & GFER & $\begin{array}{c}\text { Growth factor, augmenter } \\
\text { of liver regeneration }\end{array}$ & Growth factor & $\begin{array}{l}\text { Progressive myopathy/congenital cataract/sensorineural } \\
\text { hearing loss/developmental delay }\end{array}$ & AR & MD & 600924 & $\begin{array}{c}{[43]} \\
(2009)\end{array}$ \\
\hline & & $A B A T$ & $\begin{array}{l}\text { 4-aminobutyrate } \\
\text { aminotransferase }\end{array}$ & Aminotransferase & Encephalomyopathy & $\mathrm{AR}$ & $\mathrm{D}$ & 137150 & $\begin{array}{c}{[44]} \\
(2015)\end{array}$ \\
\hline & & $F B X L 4$ & F-box/LRR-repeat protein 4 & Protein homeostasis & Encephalomyopathy & $\mathrm{AR}$ & $\mathrm{D}$ & 605654 & $\begin{array}{c}{[45]} \\
(2013)\end{array}$ \\
\hline & & MRM2 & $\begin{array}{c}\text { rRNA methyltransferase } 2, \\
\text { mitochondrial }\end{array}$ & $\begin{array}{l}\text { Mito rRNA } \\
\text { maturation }\end{array}$ & MELAS-like & AR & $\mathrm{D}$ & 606906 & $\begin{array}{c}{[46]} \\
(2017)\end{array}$ \\
\hline & & $C 1 Q B P$ & $\begin{array}{l}\text { Complement component } 1 \\
\text { Q subcomponent-binding } \\
\text { protein, mitochondrial }\end{array}$ & $\begin{array}{l}\text { Inflammation/nuclear } \\
\text { transcrip- } \\
\text { tion/mitoribosome } \\
\text { biogenesis/apoptosis }\end{array}$ & Cardiopathy-multisystemic/PEO-myopathy & AR & MD & 601269 & $\begin{array}{c}{[47]} \\
(2017)\end{array}$ \\
\hline
\end{tabular}

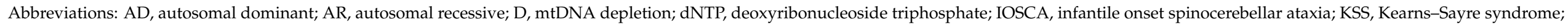

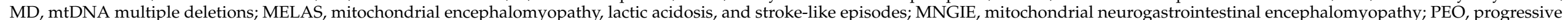

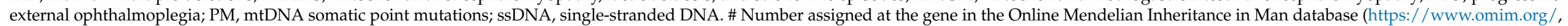
accessed on 22 May 2021); ${ }^{*}$ The first report associating mutations in the gene to a disease with mtDNA alterations. 
The first protein in this list is polymerase gamma, the mitochondrial replicase [50]. It is a heterotrimer constituted of a large subunit of $140 \mathrm{kDa}$ encoded by POLG that has the catalytic activities $\left(5^{\prime}-3^{\prime}\right.$ polymerase, $5^{\prime}$ deoxyribose phosphate lyase and proofreading $3^{\prime}-5^{\prime}$ exonuclease), and a homodimeric subunit formed by two small peptides of $55 \mathrm{kDa}$, each encoded by POLG2, which acts as a DNA binding factor providing processivity to the complex [49]. Mutations in POLG are the most frequent genetic cause of MDDS (in fact, the main cause of mitochondrial diseases) [51]. More than 300 mutations affecting all the domains of the protein have been described in POLG (https://tools.niehs.nih.gov/ /polg/, accessed on 22 May 2021), affecting both polymerase and proofreading activities, and resulting in mtDNA depletion, multiple deletions and point mutations [51,52].

Mutations in POLG cause many different syndromes with variable severities (either paediatric or adult disorders, and with recessive or dominant inheritance). These include Alpers-Huttenlocher Syndrome (AHS), sensory ataxic neuropathy, disarthrya and ophthalmoparesis (SANDO), neurogaostrointestinal encephalomyopatic syndrome (MNGIE type), and dominant or recessive progressive external ophthalmoplegia (PEO). A recent study compiling 155 patients with mutations in POLG found that neurological, ophthalmological and gastrointestinal are the most frequently reported symptoms. Moreover, the symptoms are associated with the age of onset, with feeding difficulties and seizures being the most common symptoms in people under 12 years, and ataxia, peripheral neuropathy and seizures in patients between 12 and 40 years of age and ptosis, $\mathrm{PEO}$ and ataxia in patients with onset above 40 years [53]. Mutations in POLG2, encoding the ancillary subunit of polymerase gamma, are much rarer than those found in $P O L G$, but since the number of patients with new pathogenic mutations in POLG2 is increasing, it has become evident that the range of phenotypes is also variable $[17,54]$, including fulminant cases $[55,56]$.

Additionally, in 2001, mutations in TWNK (formerly called C10orf2) were associated with cases of autosomal dominant progressive external ophthalmoplegia (adPEO) with multiple mtDNA deletions [18]. This gene encodes twinkle, a homohexameric $5^{\prime}-3^{\prime}$ DNA mitochondrial helicase that unwinds the double-stranded mtDNA exposing the single strands to the polymerase gamma to be used as a template for replication [57]. Mutations in TWNK found in adPEO patients with multiple deletions affect its helicase activity, stall the replication fork and cause mtDNA depletion in vitro, and also in some in vivo conditions (transgenic mice expressing adPEO variants) [58]. These observations support the notion that mtDNA depletion and multiple deletions are triggered by similar dysfunctional events. In fact, TWNK mutations also cause mtDNA depletion, associated with more severe phenotypes, such as infantile onset spinocerebellar ataxia (IOSCA) [59], or other phenotypic variants associated with mtDNA multiple deletions such as Perrault syndrome [60,61]. Interestingly, mtDNA somatic point mutations at the control region have been found in the skeletal muscle of patients with MDDS caused by mutations in POLG and TWNK [62], but to a lesser extent than those found in MNGIE patients caused by mutations in TYMP [63] (see below), which underlines the fact that the generation of somatic point mutations in mtDNA is another molecular feature of MDDS, although less prominent (and likely less functionally relevant) than depletion or multiple deletions.

As shown in Table 1, mutations in many other proteins belonging to the mtDNA replication/repair machinery have been gradually identified since 2013 [19-25,64,65], probably owing to the widespread introduction of deep sequencing methodology for genetics diagnostic. The group includes genes involved in mtDNA repair (DNA2, and possibly MGME1) and other long-ago known proteins participating in mtDNA replication such as mtSSB and TFAM. The range of different phenotypes associated with these disorders is also wide, from mild or moderate myopathy to severe phenotypes with multisystem involvement.

\subsection{Genes Involved in dNTP Metabolism}

The second group of genes associated with MDDS is constituted by genes encoding enzymes that catalyse reactions of dNTP metabolism. Since mtDNA needs a balanced supply 
of dNTPs for replication and repair, it is not surprising that mutations in these genes cause mtDNA alterations. Some of the MDDS that are currently treated with specific therapies belong to this group and their therapeutic approaches are targeted to modify/correct dNTP homeostasis (see Sections 4.5 and 4.6 below). Therefore, we will pay special attention to dNTP metabolism in this review.

There are two anabolic pathways to obtain dNTPs in cells: the de novo pathway that is fully active in dividing cells only, and the salvage pathway that recycles deoxyribonucleosides from endogenous turnover and from the diet and takes place in both dividing and nondividing cells. In addition, catabolism (consecutive dNTP dephosphorylation and further degradation of the resulting deoxyribonucleosides) also contributes to dNTP homeostasis. Alterations in both anabolic and catabolic pathways are involved in MDDS (Figure 1).

\subsection{1. dNTP Anabolism \\ De Novo Pathway}

The main source of nucleotides (which includes dNTPs) is the de novo pathway, which takes place in the cytosol and is fully active in S phase. Small molecules such as amino acids and $\mathrm{CO}_{2}$ are used as substrate precursors to obtain nucleoside diphosphates (NDPs), which are then reduced to deoxyribonucleoside diphosphates (dNDPs) by the ribonucleotide reductase (RNR). RNR is a key enzyme in the de novo pathway that works as a heterotetramer composed of two copies of a large catalytic subunit (R1 encoded by RRM1) and two copies of a small subunit that can be presented in two isoforms (R2 encoded by $R R M 2$, or p53R2 encoded by $R R M 2 B$ ). During $\mathrm{S}$ phase, the complex RNR is composed by $2 R 1 / 2 R 2$ while in cells out of the $S$ phase, the transcription of subunit $R 2$ is inhibited, $\mathrm{R} 2$ subunits are degraded, and R1 thus solely interacts with p53R2, which is expressed throughout the cell cycle. The activity of the complex $2 \mathrm{R} 1 / 2 \mathrm{R} 2$ is higher than $2 \mathrm{R} 1 / 2 \mathrm{p} 53 \mathrm{R} 2$ because in the $S$ phase, the needs of dNTPs are much higher than in the rest of the cell cycle [66]. The dNDPs formed as products of RNR catalysis are then further phosphorylated by nucleoside diphosphate kinases (NDPKs) to dNTPs, the building blocks of DNA. There is biochemical evidence that deoxyribonucleotides can be imported from cytosol to mitochondria $[67,68]$, and specific transporters for pyrimidine nucleotides have been identified [69-71]. The dNTP de novo pathway also depends on the enzyme thymidylate synthase (TS) that methylates deoxyuridine monophosphate (dUMP) using methylenetetrahydrofolate (MTHF) as a methyl donor, to generate thymidine monophosphate (dTMP). dTMP is further phosphorylated by thymidine monophosphate kinase (TMPK) and NDPK to obtain dTTP. Both TS and TMPK are cell cycle regulated and are mainly expressed in $S$ phase [66].

Mutations in one gene belonging to the de novo pathway, $R R M 2 B$, have to date been associated with MDDS. As mentioned above, $R R M 2 B$ encodes p53R2, the p53-regulated small subunit of RNR. Initially, mutations in this gene were associated with a fatal encephalomyopathic form of MDDS with renal tubulopathy and profound mtDNA depletion [29]; however, further cases have been associated with less severe phenotypes, such as MNGIElike clinical presentations [72], or dominant or recessive PEO and PEO-plus associated with mtDNA multiple deletions [73-77].

\section{Salvage Pathway}

As indicated above, the dNTP salvage pathway recycles deoxyribonucleosides (dNs) derived from diet or from cellular metabolism (DNA degradation, de novo synthesis) to dNTPs. It takes place in both cytosol and mitochondria and it is not cell-cycle regulated. It relies on two parallel sets of enzymes in cytosol and mitochondria that sequentially phosphorylate $\mathrm{dNs}$ to dNTPs. The first phosphorylation (from $\mathrm{dN}$ to $\mathrm{dNMP}$ ) is the rate-limiting step; in the cytosol, it is catalysed by thymidine kinase 1 (TK1), which phosphorylates thymidine, dThd (and also deoxyuridine, dUrd), and deoxycytidine kinase (dCK) that phosphorylates deoxycytidine (dCtd), deoxyadenosine (dAdo) and deoxyguanosine (dGuo). The equivalent enzymes in mitochondria are thymidine kinase 2 (TK2), which phospho- 
rylates the pyrimidine $\mathrm{dNs}$ (dThd, $\mathrm{dCtd}$ and $\mathrm{dUrd}$ ), and deoxyguanosine kinase (dGK), which phosphorylates the purine $\mathrm{dNs}$ (dAdo and dGuo). dNMPs produced in these first steps are further phosphorylated by nucleoside monophosphate kinases (NMPKs) and nucleoside diphosphate kinases (NDPKs), before finally obtaining dNTPs.

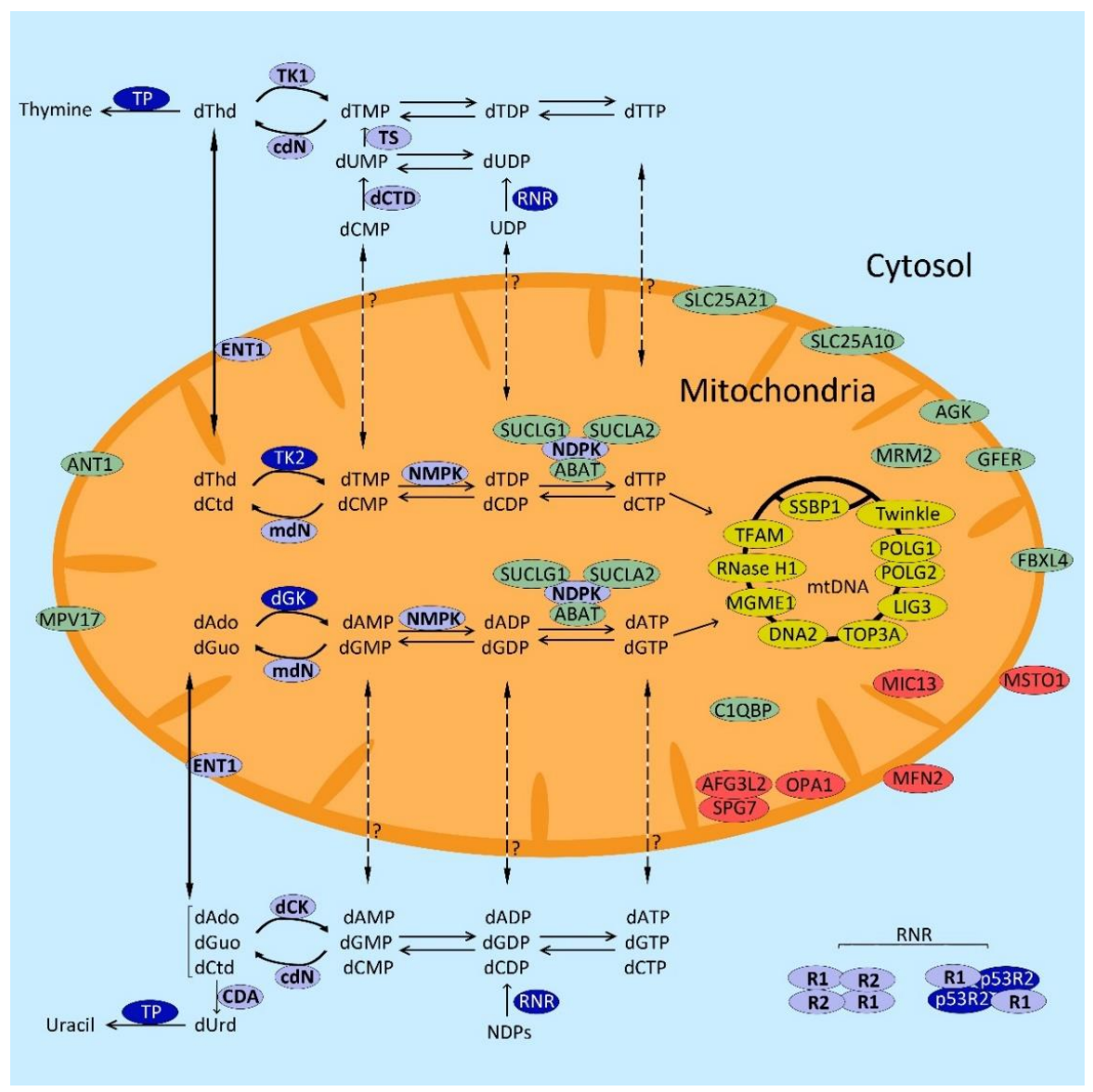

Figure 1. Metabolic pathways and proteins involved in mitochondrial DNA replication disorders. Proteins whose mutations have been linked to MDDS are depicted in yellow (mtDNA replication/maintenance machinery), dark blue (dNTP metabolism), red (mitochondrial dynamics) and green (unknown role in mtDNA replication). Light blue colour represents proteins participating in dNTP metabolism but not associated with MDDS. Abbreviations: ABAT, 4-aminobutyrate aminotransferase; AFG3L2, AFG3-like protein 2; AGK, acylglycerol kinase; ANT1, adenine nucleotide translocator 1; CDA, cytidine deaminase; $c d N$, cytosolic deoxyribonucleotidase; C1QBP, complement component 1 Q subcomponent-binding protein; dAdo, deoxyadenosine; dCK, deoxycytidine kinase; dCtd, deoxycytidine; dCTD, deoxycytidylate deaminase; dGK, deoxyguanosine kinase; dGuo, deoxyguanosine; DNA2, helicase/nuclease DNA2; dThd, thymidine; dUrd, deoxyuridine; ENT1, equilibrative nucleoside transporter 1; FBXL4, F-box/LRR-repeat protein 4; GFER, growth factor, augmenter of liver regeneration; LIG3, ligase III; mdN, mitochondrial deoxyribonucleotidase; MFN2, mitofusin 2; MGME1, mitochondrial genome maintenance exonuclease 1; MICOS13, MICOS complex subunit MIC13; MPV17, protein MPV17; MRM2, rRNA methyltransferase 2; MSTO1, protein misato homolog 1; NDPK, nucleoside diphosphate kinase; NMPK, nucleoside monophosphate kinase; OPA1, dynamin-like 120 kDa protein; POLG1, catalytic subunit of polymerase gamma; POLG2, ancillary subunit of polymerase gamma; p53R2; p53-inducible small subunit of the ribonucleotide reductase; R2, small subunit of the ribonucleotide reductase; RNASEH1, ribonuclease H1; RNR, ribonucleotide reductase; SLC25A10, mitochondrial dicarboxylate carrier; SLC25A21, mitochondrial 2-oxodicarboxylate carrier; SPG7, paraplegin; SSBP1, mitochondrial single strand binding protein; SUCLA2, $\beta$-subunit of the succinate-CoA ligase; SUCLG1, $\alpha$-subunit of the succinate-CoA ligase; TFAM, mitochondrial transcription factor 1; TK1, thymidine kinase 1; TK2, thymidine kinase 2; TOP3A, DNA topoisomerase 3 alpha; TP, thymidine phosphorylase; TS, thymidylate synthase; Twinkle, mitochondrial helicase. Right bottom corner: the 2 isoforms of tetrameric RNR are represented, 2R1/2R2 (active in proliferating cells) and 2R1/2p53R2 (active throughout the cell cycle). Question marks indicate that the mitochondrial transporter(s) of the deoxyribonucleoside mono-, di- and triphosphates has or have not been identified. Figure generated using the Adobe ${ }^{\circledR}$ Photoshop ${ }^{\circledR}$ CS5 software. 
Mutations in TK2 and DGUOK (encoding TK2 and dGK) are associated with severe MDDS [27,28]. Mutations in TK2 cause a myopathic form with a considerable clinical variability, ranging from severe presentations that result as fatal in infancy or childhood, associated with marked mtDNA depletion in muscle, to less severe presentations that are usually associated with mtDNA multiple deletions, with slower clinical progression or even onset in adulthood [78]. DGUOK mutations cause severe hepatopathy or hepatocerebral syndrome with mtDNA depletion in infants, although myopathic cases with multiple deletions have also been reported $[28,79,80]$.

\subsection{2. dNTP Catabolism}

dNTPs are catabolized through consecutive dephosphorylating reactions (reverse to those described for the salvage pathway) and further degradation of the resulting dNs. Several specific enzymes catalyse some catabolic reactions biochemically different than those mediated by the anabolic enzymes, thus constituting independent regulatory catabolic steps. 5' -nucleotidases, with several isoforms including a mitochondrial isoform encoded by NT5M [81], catalyse the hydrolytic dephosphorylation of the monophosphates, and together with the anabolic (deoxy)ribonucleoside kinases, constitute substrate cycles that regulate cytosolic and mitochondrial monophosphate concentrations at the expense of ATP consumption [81]. SAMHD1, is a cytosolic triphosphohydrolase that catalyses the direct dephosphorylation of dNTPs to dNs [82], and dCTP pyrophosphatase 1 hydrolyses dNTPs to the corresponding monophosphates $[83,84]$. dN degradation is initiated by cytidine deaminase (CDA, conversion of dCtd to dUrd), adenosine deaminase (ADA, conversion of dAdo to deoxyinosine, dIno). The resulting $\mathrm{dNs} \mathrm{dUrd}$ and dIno, together with the canonical dGuo and dThd, are broken by phosphorolysis by purine nucleoside phosphorylase (PNP, for dGuo and dIno) and thymidine phosphorylase (TP, for dThd and dUrd).

The latter enzyme, TP, is encoded by TYMP, and it is the only nucleotide/nucleoside catabolic enzyme associated with MDDS. Mutations in TYMP cause mitochondrial neurogastrointestinal encephalomyopathy (MNGIE), a recessive disorder characterized by gastrointestinal dismotility, cachexia, ptosis, progressive external ophtalmoplegia, peripheral neuropathy and leukoencephalopathy $[15,26,85]$. As a consequence of TP dysfunction, MNGIE patients present elevated systemic concentrations of dThd and dUrd. Experimental results show that this $\mathrm{dN}$ overload results in increased dTTP levels and secondary dCTP depletion in mitochondria, which interferes with mtDNA replication and maintenance, causing secondary mtDNA depletion in vitro and in organello [86-89]. In vivo results obtained in a genetic murine model of the disease confirmed these biochemical disarrangements [90]. As a consequence of this dNTP imbalance, MNGIE patients present mtDNA depletion, multiple deletions and somatic point mutations [15,63,91]. As the toxic effect of dThd and dUrd on mtDNA is the biochemical imbalance triggering the phenotype in MNGIE, most therapy approaches aim to eliminate these nucleosides using different strategies (see Section 4 below).

The de novo pathway is active in replicating cells, providing elevated dNTP cellular levels needed for nuclear DNA replication. Post-mitotic cells downregulate the de novo pathway, have reduced dNTP levels, and thus become much more dependent on the cytosolic and mitochondrial salvage pathways. In the particular case of the dThd, the cytosolic salvage pathway is also inhibited, because TK1 is downregulated. Therefore, the salvage of dThd mainly depends on the mitochondrial TK2 in quiescent cells [68].

\subsubsection{Nucleoside/Nucleotide Transporters}

As mentioned above, biochemical evidence indicates that deoxyribonucleotides can be exchanged between cytosol and mitochondria through the inner mitochondrial membrane $[67,68]$, and some of the mitochondrial transporters have been identified [69-71]. Although mitochondrial and cytosolic dNTP pools are different, they are not mutually independent, and deoxyribonucleotide transport across the mitochondrial membrane con- 
tributes to keep a balanced dNTP composition in both compartments. Mitochondrial import likely predominates in dividing cells, while there is also evidence of mitochondrial export in quiescent state, at least for the deoxyribonucleotides of thymidine [67].

On the other hand, plasma membranes are impermeable to nucleotides because they do not have transporters enabling the internalization of these charged compounds [92]. Instead, nucleoside and nucleobase transport between the cell and the extracellular milieu is mediated by two families of carriers, with different isoforms having different substrate selectivity: the solute carrier family 28 (SLC28 genes) encoding the concentrative nucleoside transporters CNT (CNT1-3), and the solute carrier family 29 (SLC29 genes) encoding the equilibrative nucleoside transporters ENT (ENT1-4). Concentrative and equilibrative transporters are located in the plasma membranes of cells, with different distribution in different cells and even different regions of the plasma membrane to promote vectorial nucleoside transport through the cell $[93,94]$. Thus far, only one of these transporters, ENT1, has been found in the mitochondrial membrane [95].

Although mutations in some nucleoside transporters may be pathogenic [96,97], to date, no mitochondrial diseases have been associated with mutations in these genes. However, these transporters are very important in biomedicine, as they are obligated mediators for some nucleotide-based therapies, such as chemotherapy for cancer or some antivirals [93], and they should also be involved in some of the emerging therapies for MDDS discussed in Section 4 below.

\subsection{Genes Involved in Mitochondrial Dynamics}

A functional mitochondrial dynamics is essential for mtDNA replication because the fission and fusion of the organelle allow mitochondria to exchange components of the matrix, thus facilitating a balanced composition of the mitochondrial dNTP pool and mtDNA replication enzymes, as well as an even distribution of mtDNA molecules throughout the cellular mitochondrial network [98,99].

Mitochondria mix through the coordinated fusion of the outer and inner membranes by the action of three GTPases: mitofusin 1 (MFN1) and 2 (MFN2) mediate the fusion of the outer mitochondrial membrane while the dynamin-related protein OPA1 is essential for inner membrane fusion [99]. In addition, OPA1 encodes an alternatively spliced isoform, OPA1-exon $4 \mathrm{~b}$, that is associated with the mitochondrial inner membrane and directly interacts with the nucleoids, allowing their distribution within the mitochondrial network. OPA1-exon $4 \mathrm{~b}$ also promotes mtDNA replication by interacting with and regulating the replisome [100]. Thus, it is not surprising that dysfunctional mitochondrial dynamics interferes with the correct replication of mtDNA, although the details of the molecular mechanisms accounting for the reduction in the mtDNA copy number or the occurrence of multiple deletions may be different for mutations in different genes of this category, and so these molecular details need to be specifically explored for each gene.

Mutations in MFN2 and OPA1 cause MDDS, presenting as optic atrophy, myopathy, axonal neuropathy and Charcot-Marie-Tooth disease in the case of MFN2 [31] and optic atrophy and Behr syndrome in the case of OPA1 [30]. Protein misato homolog 1, encoded by MSTO1, is associated with the mitochondrial outer membrane and participates in mitochondrial distribution and network formation [101]. Mutations in MSTO1 cause myopathy and ataxia [34]. MICOS13 encodes MIC13, a subunit of the mitochondrial contact site and cristae junction organizing system (MICOS). Mutations in this gene cause liver mtDNA depletion, OXPHOS deficiency and fewer cristae structures [35,102]. Paraplegin, encoded by SPG7, and AFG3L2, are components of the m-AAA protease complex, located in the inner mitochondrial membrane. This proteolytic complex degrades misfolded proteins and regulates ribosome assembly $[32,103]$. Recently, it has been described that mutations in AFG3L2 destabilize OPA1 leading to mitochondrial fragmentation [104]. Mutations in SPG7 and AFG3L2 have been associated with PEO accompanied by movement disorders with mtDNA multiple deletions in muscle [32,33,105]. 


\subsection{Genes Involved in mtDNA Maintenance through Unknown Mechanisms}

Approximately one third of all genes associated with MDDS to date encode proteins that do not have a clear functional link with mtDNA replication. This group constitutes the last category of genes listed in Table 1 . Some classifications include several of these genes (SLC25A4, AGK, SUCLA2, SUCLG1, ABAT, MPV17) as related with nucleotide metabolism [106], however, we prefer to restrict this group to genes that directly participate in dNTP homeostasis, as these are the actual substrates of mtDNA replication. SLC25A4 encodes ANT1, the muscle isoform of the ADP / ATP mitochondrial translocator (adenine nucleotide translocator, ANT). ATP and ADP nucleotides are not mtDNA building blocks, therefore, the reason why mutations in this gene produce mtDNA multiple deletions seems not to be directly related with dNTP imbalance. Mutations in this gene were associated with myopathy with mtDNA multiple deletions as early as 2000 [36].

Similarly, mutations in $A G K$ have been associated with mtDNA depletion in Sengers syndrome [42,107]. This gene encodes the enzyme acylglycerol kinase that phosphorylates monoacylglycerol and diacylglycerol to phosphatidic acid, an intermediate to synthesize membrane lipids such as cardiolipin. Since this lipid is associated with ANT [108], it has been hypothesized that AGK could play a role in nucleotide import via ANT by regulating the lipid composition of the inner mitochondrial membrane, and thus this gene is sometimes classified in the group of dNTP-related genes. However, as pointed out above, ANT does not regulate dNTPs and there is no obvious reason to assume that it participates in dNTP homeostasis. Mutations in SUCLA2 and SUCLG1 have been associated with encephalopathy with mtDNA depletion $[40,41]$. These genes encode two subunits of Krebs cycle enzyme succinate CoA ligase. Although this protein is a molecular partner of the mitochondrial isoform of the dNTP anabolic enzyme nucleoside diphosphate kinase (NDPK) [109], the assumption that mutations in SUCLA2 and SUCLG1 disrupt dNTP homeostasis because of this molecular association has not been supported by experimental data. $A B A T$ encodes the mitochondrial enzyme gamma-aminobutyrate aminotransferase, which catalyses the catabolic deamination of the neurotransmitter gamma-aminobutyric acid (GABA). The main reason that this enzyme has been claimed to have a role in dNTP homeostasis relies on the observation that dNTP addition rescues mtDNA depletion, as observed in $A B A T$-deficient cultured cells [44]. In fact, $\mathrm{dNs}$ are the actual molecules that enter the cell after dNTP addition to the cell culture [92], and the enhancement of mtDNA replication by intracellular $\mathrm{dN}$-stimulated dNTP synthesis has been observed for deficiencies other than those directly related with dNTP synthesis $[110,111]$. In fact, increased dNTP availability may increase mtDNA copy number even in fully functional cells [112]. Similarly, although dN supplementation can rescue mtDNA depletion in MPV17 mutants in vitro and in vivo [111], it has not yet been demonstrated that the membrane protein transporter MPV17 (associated in patients with severe neurohepatopathy with mtDNA depletion [37]) has a role as a nucleotide carrier. Therefore, the biochemical mechanisms accounting for the defective mtDNA replication/maintenance observed in patients with mutations in SLC25A4, AGK, SUCLA2, SUCLG1, ABAT and MPV17 remain to be clarified.

The biological function of the proteins included in this last category is variable, and the severity and phenotype features of the patients is as diverse as those observed in the other categories. Interestingly, four genes of this group encode transporters located in the inner mitochondrial membrane, functioning as carriers of different molecules. In addition to the aforementioned carriers ANT1 and MPV17, mutations in two additional genes (SLC25A21, SLC25A10) encoding two mitochondrial dicarboxylate transporters have been found in patients with mtDNA depletion [38,39]. The other genes of this group include GFER and FBXL4. GFER encodes a growth factor whose mutations cause myopathy, congenital cataract and developmental delay. In vitro, mutations in GFER are associated with mtDNA multiple deletions in patients' myoblasts but not in fibroblasts $[43,113]$. FBXL4 encodes a protein located in the mitochondrial intermembrane space that belongs to the F-box family, whose exact function is not yet known. Although proteins of this family participate in Skp1-cullin1-F-box (SCF)-dependent proteasomal ubiquitin-dependent protein catabolic 
process, FBXL4 has also been associated with mitochondrial dynamics [106]. However, studies conducted in Fbxl4 knockout mice have revealed that the molecular phenotype caused by FBXL4 mutations (mtDNA depletion observed in patients [45]) may be mediated by a global decrease in mitochondrial content due to the dysregulation of autophagy rather than a primary dysfunctional mtDNA maintenance [114]. C1QBP (complement component $1 \mathrm{Q}$ subcomponent-binding protein) is a mitochondrial matrix protein of unknown function which is thought to be involved in inflammation and mitochondrial ribosome synthesis. Patients with a clinic of PEO carrying mutations in this gene showed mtDNA multiple deletions in muscle but not depletion [47,115].

Three of the genes quoted at the OMIM database were associated with mtDNA depletion (OMIM: Phenotypic Series-PS603041, mitochondrial DNA depletion syndrome) have been reported in isolated single cases to date (SCL25A21 [38], SCL25A10 [39] and MRM2 [46]), and for two of these, the reported degree of mtDNA depletion is mild (SCL25A10 and MRM2). It is expected that new cases of MDDS patients with mutations in these genes will confirm their association with mtDNA replication disorders.

\section{Non-Targeted Therapies for Mitochondrial DNA Maintenance Disorders}

MDDS are mitochondrial disorders. The OXPHOS dysfunction derived from the somatic mtDNA alteration is the factor causing the clinical presentation in MDDS patients. As with other mitochondrial diseases, treatments conceived to ameliorate mitochondrial dysfunction are often applied to MDDS patients even when acting through non-targeted or unspecific mechanisms, and some of the experimental approaches under preclinical investigation have also been explored in MDDS models.

\subsection{Symptomatic Treatments and Other Non-Targeted Treatments Applied to MDDS Patients}

MDDS are diseases with poor prognosis in the majority of patients and there is currently no curative therapy for any of them [116]. Therefore, with the exception of some isolated cases in which investigational targeted treatments are applied under compassionate use or have initiated a clinical trial, current treatments focus on mitigating the symptoms and preventing further complications. The main advantage of these treatments is that, in principle, they can be applied to all MDDS patients regardless of the genetic cause, although their real efficacy or impact on the disease can be mild due to their generalist mechanism of action.

Seizures is one of the serious manifestations that may occur in MDDS patients (observed in some forms caused by mutations in POLG, TWNK and others [117]). They can be treated with antiepileptic drugs, but valproate is not recommended, because mitochondrial dysfunction is a risk factor for valproate-induced liver failure [118]. Nasogastric tube or gastrostomy tube feedings are ways to treat the feeding difficulties and failure to thrive. Chest physiotherapy, artificial ventilation, tracheostomy or ventilators can be used to treat respiratory insufficiency. Other treatments include the surgical treatment of scholiosis, kyphosis, or ptosis and cochlear implantation in the cases of hearing loss [119].

Special diets are also a possibility used in some mitochondrial diseases [116,120]. Options such as continuous feeding in order to prevent hypoglycaemia [119], or the administration of ketogenic high-fat low carbohydrate diet to stimulate beta-oxidation, can be recommended depending on the specific presentation of the patient. Ketogenic diet reduced the heteroplasmic load in cybrids carrying mtDNA single deletion [121] and slowed down myopathy progression in mice [122].

Supplementation with key compounds of the ETC is a widely used treatment for MDDS. For instance, succinate and ubiquinone have been used to slow down liver dysfunction in MPV17 patients [123], and treatments with oral folinic acid [124], levocarnitine, carnitine, coenzyme Q10, idibenone, alpha lipoic acid, and vitamins C, E and B are also used, often together as a cocktail [125]. Nevertheless, the evidence of their effectiveness is short [126] and there are no standard guides recommending any specific cocktail of compounds. 
Physical therapy can help maintain muscle tone and function [119]. Moreover, it has been described that exercise stimulates mitochondrial biogenesis and thus counteracts the oxidative dysfunction [127]. Additionally, a published review of the literature recommends endurance and resistance exercise [128].

\subsection{Non-Targeted Experimental Approaches}

Several non-targeted experimental strategies have been proposed to fight mitochondrial dysfunction, such as the activation of mitochondrial biogenesis to compensate ATP depletion [129], the inhibition of mTORC1, which is an activator of anabolic pathways and an inhibitor of autophagy [130], hypoxia [131] or bypassing the OXPHOS defects with non-mammalian alternative oxidase expression [132]. None of these strategies have been tested in any preclinical model of MDDS, with the exception of mTORC1 inhibition, which has been tested in a TK2 knock in mouse model of MDDS. Low-dose rapamycin extended the lifespan of the TK2-deficient mice by nearly two-fold. Interestingly, the treatment did not rescue mtDNA depletion, and did not prevent mitochondrial dysfunction but induced metabolic changes, likely promoting the use of alternative energy reserves and a developmental reprogramming that ultimately prolongs survival [133].

Treatments addressing primary mutations in mtDNA, such as mitochondrial replacement therapy [134] or mtDNA heteroplasmy shifting [135], could hardly be applied to MDDS patients.

\section{Targeted Therapies for MDDS}

The first patients with mtDNA depletion and multiple deletions were reported long ago [136,137], and the first genetic cause for one of the MDDS was found in 1999 [26]. The significant advances in our knowledge of the biochemical and molecular pathomechanisms accounting for dysfunctional mtDNA replication in many of these disorders, gained over the two last decades, have opened the possibility to design and study tailored strategies to fight the specific cause of each form of MDDS. Although these therapies are normally designed to specifically address a particular defect, they can, in some cases be extended to disorders with a different aetiology but a common underlying biochemical or molecular defect, likely being more effective than general non-targeted treatments. Some of these approaches are still in the preclinical phases, but in some cases, they have already reached the clinical trial phase (Table 2).

\subsection{Direct Scavenging of Toxic Metabolites}

Although there are other mitochondrial diseases caused by the toxic effect of accumulated metabolites [138], mitochondrial neurogastrointestinal encephalomyopathy (MNGIE) is the only disease falling in the category of MDDS, to date identified as caused by this type of biochemical noxious effect. In MNGIE, mtDNA replication is interfered by the dNTP imbalances caused by the systemic accumulation of dThd and dUrd, which are the substrates of the dysfunctional enzyme thymidine phosphorylase [87,89]. Therefore, most therapy strategies proposed for MNGIE patients, including allogeneic hematopoietic stem cell transplantation (AHSCT) or liver transplantation, aim at clearing the biochemical excess of these compounds (see below).

Since dThd and dUrd are filterable water-soluble molecules, the first therapeutic approach for MNGIE was haemodialysis. However, this method was ineffective because the reduction in circulating dThd levels was suboptimal (not reaching normal values) and transient. Three hours after the dialysis, plasma dThd levels returned to their initial values, even after several consecutive repeated rounds of dialysis [89]. More recent results showed that haemodialysis does not remove excessive metabolites from the cerebrospinal fluid (CSF) [139]. Likewise, continuous ambulatory peritoneal dialysis has been attempted but its effects were also transient [140]. Peritoneal dialysis has been proposed as a bridge or maintenance treatment for patients while they wait for a compatible donor for AHSCT or liver transplantation [85]. 
Table 2. Clinical trials recruiting patients with mitochondrial DNA replication disorders. Only ongoing or recently conducted clinical trials accepting patients with MDDS are listed.

\begin{tabular}{|c|c|}
\hline NCT04378075 & $\begin{array}{l}\text { A Study to Evaluate Efficacy and Safety of Vatiquinone for Treating } \\
\text { Mitochondrial Disease in Participants with Refractory Epilepsy }\end{array}$ \\
\hline Condition & POLG \\
\hline Study type/phase & Interventional (phase 2 and phase 3 ) \\
\hline Intervention & Vatiquinone administration \\
\hline Status & Recruiting \\
\hline Estimated study completion & 1 April 2023 \\
\hline Outcomes & $\begin{array}{l}\text { Change in the number of observable motor seizures } \\
\text { Occurrence or recurrence of epilepsy } \\
\text { Participants who require rescue seizure medication }\end{array}$ \\
\hline Sponsor & PTC therapeutics \\
\hline NCT01370447 & EPI-743 for Mitochondrial Respiratory Chain Diseases \\
\hline Condition & POLG \\
\hline Study type/phase & Interventional (phase 2) \\
\hline Intervention & EPI-743 \\
\hline Status & Active, not recruiting \\
\hline Estimated study completion & 31 December 2021 \\
\hline Outcomes & $\begin{array}{c}\text { Change in neuromuscular function } \\
\text { Number of subjects experiencing adverse events } \\
\text { Change in Newcastle Paediatric Mitochondrial Disease Score } \\
\text { Pharmacokinetics of EPI-743 }\end{array}$ \\
\hline Sponsor & PTC Therapeutics \\
\hline NCT02023866 & $\begin{array}{l}\text { Open-Label, Dose-Escalating Study Assessing Safety, Tolerability, Efficacy, of } \\
\text { RP103 in Mitochondrial Disease }\end{array}$ \\
\hline Condition & POLG-TYMP \\
\hline Study type/phase & Interventional (phase 2) \\
\hline Intervention & Cysteamine bitartrate \\
\hline Status & Completed \\
\hline Estimated study completion & October 2016 \\
\hline Outcomes & Change in Newcastle Paediatric Mitochondrial Disease Scale (NPMDS) Score \\
\hline Sponsor & Horizon Pharma USA, Inc. \\
\hline NCT02473445 & $\begin{array}{c}\text { A Long-Term Extension of Study RP103-MITO-001 (NCT02023866) to Assess } \\
\text { Cysteamine Bitartrate Delayed-Release Capsules (RP103) in Children with } \\
\text { Inherited Mitochondrial Disease }\end{array}$ \\
\hline Condition & POLG-TYMP \\
\hline Study type/phase & Interventional (phase 2) \\
\hline Intervention & Cysteamine bitartrate \\
\hline Status & Completed \\
\hline Estimated study completion & 6 March 2017 \\
\hline Outcomes & Change in Newcastle Paediatric Mitochondrial Disease Scale (NPMDS) Score \\
\hline Sponsor & Horizon Pharma USA, Inc. \\
\hline
\end{tabular}


Table 2. Cont.

\begin{tabular}{|c|c|}
\hline NCT03701568 & A RETROspective Study of Patients with TK2d \\
\hline Condition & TK2 \\
\hline Study type/phase & Observational \\
\hline Intervention & $\mathrm{dCtd} / \mathrm{dThd}$ \\
\hline Status & Completed \\
\hline Estimated study completion & 31 May 2019 \\
\hline Outcomes & $\begin{array}{c}\text { Clinical course } \\
\text { Motor function and ambulatory assessments }\end{array}$ \\
\hline Sponsor & Modis Therapeutics, Inc. \\
\hline NCT03845712 & $\begin{array}{l}\text { An Open-Label Study of Continuation Treatment with Combination } \\
\text { Pyrimidine Nucleosides in Patients With TK2 }\end{array}$ \\
\hline Condition & TK2 \\
\hline Study type/phase & Interventional (phase 2) \\
\hline Intervention & MT1621 \\
\hline Status & Active, not recruiting \\
\hline Estimated study completion & 31 January 2022 \\
\hline Outcomes & $\begin{array}{c}\text { Safety } \\
\text { Motor function assessments } \\
\text { Respiratory status } \\
\text { Growth/nutrition } \\
\text { Pharmacokinetics } \\
\text { Quality of life through patient questionnaire }\end{array}$ \\
\hline Sponsor & Modis Therapeutics, Inc. \\
\hline NCT04581733 & $\begin{array}{c}\text { A Study of the Efficacy and Safety of MT1621 in Thymidine Kinase } 2 \text { (TK2) } \\
\text { Deficiency }\end{array}$ \\
\hline Condition & TK2 \\
\hline Study type/phase & Interventional (phase 3) \\
\hline Intervention & MT1621 \\
\hline Status & Not yet recruiting \\
\hline Estimated study completion & March 2025 \\
\hline Outcomes & $\begin{array}{l}\text { Time to loss/acquisition of any motor milestone } \\
\text { Overall survival }\end{array}$ \\
\hline Sponsor & Modis Therapeutics, Inc. \\
\hline NCT03639701 & Treatment of TK2 Deficiency with Thymidine and Deoxycytidine \\
\hline Condition & TK2 \\
\hline Study type/phase & Interventional (phase 1 and phase 2) \\
\hline Intervention & dThd \\
\hline Status & Enrolling by invitation \\
\hline Estimated study completion & 1 April 2024 \\
\hline Outcomes & $\begin{array}{c}\text { Safety } \\
\text { Efficacy measured by different ways }\end{array}$ \\
\hline Sponsor & Columbia University \\
\hline
\end{tabular}


Table 2. Cont.

\begin{tabular}{|c|c|}
\hline NCT03866954 & $\begin{array}{l}\text { Trial of Erythrocyte Encapsulated Thymidine Phosphorylase in Mitochondrial } \\
\text { Neurogastrointestinal Encephalomyopathy }\end{array}$ \\
\hline Condition & TYMP \\
\hline Study type/phase & Interventional (phase 2) \\
\hline Intervention & EETP \\
\hline Status & Not yet recruiting \\
\hline Estimated study completion & September 2022 \\
\hline Outcomes & $\begin{array}{c}\text { Safety of procedure } \\
\text { Pharmacodynamic effects } \\
\text { Efficacy of EETP } \\
\text { Changes in clinical assessments }\end{array}$ \\
\hline Sponsor & St George's, University of London \\
\hline NCT02427178 & MNGIE Allogeneic Hematopoietic Stem Cell Transplant Safety Study \\
\hline Condition & TYMP \\
\hline Study type/phase & Interventional (phase 1) \\
\hline Intervention & Hematopoietic allogenic stem cells \\
\hline Status & Recruiting \\
\hline Estimated study completion & June 2023 \\
\hline Outcomes & $\begin{array}{c}\text { Engraftment success } \\
\text { Survival } \\
\text { Blood levels of dThd and dUrd }\end{array}$ \\
\hline Sponsor & Columbia University \\
\hline NCT00804102 & Transcorneal Electrical Stimulation Therapy for Retinal Disease \\
\hline Condition & OPA1 \\
\hline Study type/phase & Interventional (not phase applicable) \\
\hline Intervention & Transcorneal electrical stimulation \\
\hline Status & Completed \\
\hline Estimated study completion & April 2011 \\
\hline Outcomes & $\begin{array}{c}\text { Enhanced field of vision } \\
\text { Enhanced visual acuity } \\
\text { Lower threshold for electrical evoked phosphenes }\end{array}$ \\
\hline Sponsor & Okuvision $\mathrm{GmbH}$ \\
\hline NCT03011541 & Stem Cell Ophthalmology Treatment Study II \\
\hline Condition & OPA1 \\
\hline Study type/phase & Interventional (not phase applicable) \\
\hline Intervention & Administration of autologous bone marrow derived stem cells \\
\hline Status & Recruiting \\
\hline Estimated study completion & January 2022 \\
\hline Outcomes & $\begin{array}{c}\text { Visual acuity } \\
\text { Visual fields } \\
\text { Optical coherence tomography }\end{array}$ \\
\hline Sponsor & MD Stem Cells \\
\hline
\end{tabular}


Table 2. Cont.

\begin{tabular}{cc}
\hline NCT01648634 & $\begin{array}{c}\text { Nebivolol for the Prevention of Left Ventricular Systolic Dysfunction in } \\
\text { Patients with Duchenne Muscular Dystrophy }\end{array}$ \\
\hline Condition & SUCLA2 \\
\hline Study type/phase & Interventional (phase 3) \\
\hline Intervention & Nevibolol \\
\hline Status & Active, not recruiting \\
\hline Estimated study completion & June 2021 \\
\hline Outcomes & $\begin{array}{c}\text { Left ventricular systolic dysfunction } \\
\text { Right ventricular ejection fraction } \\
\text { Hospitalizations } \\
\text { Mortality }\end{array}$ \\
\hline Sponsor & \begin{tabular}{c} 
Assistance Publique-Hôpitaux de Paris \\
\hline
\end{tabular}
\end{tabular}

Abbreviations: dCtd, deoxycytidine; dUrd, deoxyuridine; dThd, thymidine; EETP, erythrocyte-entrapped thymidine phosphorylase; EPI-743, vatiquinone, alpha-tocotrienol quinone; MNGIE, mitochondrial neurogastrointestinal encephalomyopathy; MT1621, combination of thymidine and deoxycytidine for oral administration; OPA1, gene encoding the dynamin-like $120 \mathrm{kDa}$ protein, mitochondrial; $P O L G$, gene encoding the catalytic subunit of polymerase gamma; TK2, gene encoding thymidine kinase 2; TYMP, gene encoding thymidine phosphorylase; SUCLA2, gene encoding the $\beta$-subunit of succinate-CoA ligase. Data obtained from https://clinicaltrials.gov/ (accessed on 22 May 2021)

The results obtained with haemodialysis in MNGIE patients revealed that urine dThd is reabsorbed in the kidney, so it was proposed to inhibit this reabsorption to contribute to eliminate this metabolite from patients, but finding a drug that selectively inhibits the reabsorption of pyrimidine $\mathrm{dNs}$ without affecting the reabsorption of other compounds is difficult [141].

Regarding toxic metabolite accumulation in MDDS other than MNGIE, the existence of an oxidative environment favours the oxidation of cysteine to cystine, which accumulates in several tissues mainly affecting kidneys and eyes. The use of cysteamine bitartrate that catalyses the conversion of cystine to cysteine, was proposed to prevent the formation of cystine crystals. Two clinical trials assessed its efficacy in MDDS (NCT02023866 and NCT02473445, Table 2), but they were prematurely closed because of the lack of efficacy they demonstrated.

\subsection{Enzyme Replacement}

Again, enzyme replacement has only been explored for MNGIE among MDDS. The dysfunctional enzyme in this disease, $\mathrm{TP}$, is highly expressed in platelets and white blood cells $[142,143]$ where it clears the metabolites dThd and dUrd, thus contributing to the removal of these nucleosides from all organs. As these nucleosides freely equilibrate across plasma membranes through dedicated equilibrative or concentrative transporters $[93,144]$, clearance from plasma also contributes to their clearance from the tissular intracellular space. Two different strategies were designed to restore circulating TP activity in MNGIE patients, but only one of them has reached the use in patients.

The first one was based on the use of polymeric nanoreactors [145,146]. Preclinical in vitro and in vivo experiments showed that TP-loaded nanoreactors were enzymatically active and stable in blood serum, and they did not induce inflammatory response after intraperitoneal administration in mice $[145,146]$. However, no further advances on this strategy have been reported in recent years.

The second enzyme replacement strategy for MNGIE proposes the use of erythrocyte entrapped thymidine phosphorylase (EETP). This approach is based on the ex vivo encapsulation of the recombinant TP enzyme within patient's erythrocytes to be reinfused into the patient [147]. This strategy prevents immune response to exogenous TP [148]. Erythrocyte membranes are permeable to $\mathrm{dNs}$, so recombinant TP can catabolize internalized metabolites and thus reduce $\mathrm{dN}$ blood levels. The reduction in dThd and dUrd levels achieved in MNGIE patients by EETP is suboptimal and transient (blood valley levels after 
infusion of EETP to patients do not reach normal levels), and infusion should be periodically repeated every few weeks $[147,149,150]$. On the other hand, the reports indicate that this treatment improved the condition of the patients $[149,150]$. Like peritoneal dialysis, EETP can be used as a bridge therapy for MNGIE but perhaps it is not a feasible option as a definitive treatment. Currently, there is a clinical trial assessing the efficacy of this therapy [151] (see Table 2).

\subsection{Allogeneic Hematopoietic Stem Cell Transplantation (AHSCT)}

As mentioned above, platelets and white blood cells are among the richest reservoirs of TP in humans $[142,143]$. This cytosolic enzyme is not excreted and exerts its catabolic role intracellularly. Substrates (dThd and dUrd) from the extracellular compartment are internalized into the cell, where TP catalyses their phosphorolysis and then the reaction products can be further catabolized. In this way, white blood cells and platelets (as other tissues highly expressing TP, such as the liver) act as "systemic clearing reactors" for dThd and dUrd. Considering this physiological role of platelets and white cells, the possibility to treat MNGIE by AHSCT was considered.

To gain a first proof of concept for this approach, the effect of platelet infusions from healthy donors was studied in vitro and in MNGIE patients. Patients treated with this strategy reduced dThd and dUrd levels in blood, but this reduction was transient and suboptimal due to the short half-life of platelets (8-9 days) [152]. In fact, platelet infusion was not initially conceived as an actual therapy for patients (platelets would have to be infused in patients during the whole life), but as a test to prove that AHSCT would be effective in removing circulating dThd and dUrd from patients [152]. Nevertheless, some authors have tried to use platelets in other patients with similar results [153].

The first report of two patients treated with AHSCT confirmed that, after successful engraftment, circulating levels of dThd and dUrd were lowered to undetectable or barely detectable levels [154]. However, the requirement of a compatible donor, together with the need for a toxic conditioning regime before the transplantation and the potential severe adverse effects of AHSCT, make it a complex procedure associated with relevant risks. Consensus recommendations were published based on the experience collected from several cases of AHSCT in MNGIE [155]. The results of this cohort constituted a retrospective study of 24 patients treated with AHSCT, and revealed that only nine patients were alive in the last follow-up and among the 15 patients that did not survive, nine had died due to transplant-related causes while six died due to complications from MNGIE [156]. Nonetheless, there was an improvement in the body mass index, gastrointestinal manifestations and the peripheral neuropathy in the survivors, although all these positive effects were very slow and became objectively confirmed only after several years of follow up. In order to maximize the success of this intervention, AHSCT should be considered only for selected patients that are relatively healthy without severe gastrointestinal or liver affectation [157]. A recent position paper contains updated recommendations that help decide in what MNGIE cases liver transplantation (see below) is a preferable choice than AHSCT [85]. An ongoing clinical trial is studying the efficacy and safety of this treatment (see Table 2).

\subsection{Liver Transplantation}

The liver is a severely affected organ in some forms of MDDS such as those caused by mutations in DGUOK, MPV17 and others. Liver transplantation is an option for these patients, although limited to cases of isolated liver involvement, because the multi-organ affectation would not be corrected with this intervention [158]. Some patients with mutations in MPV17 have been treated with this strategy, but its efficacy is controversial because more than half of the transplanted children died in the post-transplantation period [159] (https:/ / pubmed.ncbi.nlm.nih.gov/22593919/ accessed on 22 May 2021). A recent work has reported that liver transplant is only effective in patients with mutations in MPV17 with late onset and mild phenotype [160]. Liver transplantation has also been used in 
DGUOK patients since most of them show severe hepatic dysfunction. The results have been highly uneven, with some transplanted patients surviving longer than 5 years, while in other cases non-transplanted patients had a better outcome [161]. Additionally, patients with mutations in POLG can benefit from this treatment, but only if they do not manifest Alpers-Huttenlocher syndrome, because transplantation does not revert the brain alterations [162]. In one report, liver transplantation has been applied to two adults with mutations in POLG, but only one of them survived the procedure [163]. Another reported patient lived more than 20 years after liver transplantation (following valproate-induced liver failure) with semi-independent life [164].

Liver transplantation was also proposed [165] and has been applied [166-169] in MNGIE patients. In this case, the rationale of the treatment is different. Although it is not infrequent to observe mild liver affectation in some MNGIE patients [15], cases of severe liver dysfunction have not been reported. The objective of liver transplantation in MNGIE patients is not substituting a severely damaged organ, but to use the healthy liver as a source of "enzyme replacement" of the defective TP enzyme. The liver is very rich in TP [143] and the objective of the transplantation is that the grafted healthy organ clears the accumulated toxic nucleosides on a systemic level, similarly to what is pursued with AHSCT (see Section 4.3). This treatment has been reported in six patients and all of them were alive at the time of publication [166-169]. At least two more MNGIE patients have been liver transplanted and are alive 2 years after the treatment (unreported cases treated in our centre). Although the number of patients treated with liver transplantation is lower than those treated with AHSCT, liver transplantation seems to be safer because the survival rate is better and there is no aggressive conditioning before the intervention [125]. In fact, AHSCT and liver transplantation are the only choices currently available for the permanent treatment of MNGIE, and recommending either of these two alternate treatments may depend on several patient-related factors, as discussed and advised in a recent consensus document [85].

\subsection{Administration of Deoxyribonucleosides (dNs)}

Four genes associated with MDDS encode enzymes catalysing dNTP anabolic (TK2, DGUOK, RRM2B) or catabolic (TYMP) reactions (Table 1). Some time ago, in vitro evidence showed that supplementation with dAMP and dGMP prevented mtDNA depletion in cultured fibroblasts from patients with mutations in DGUOK [170]. The effect of this treatment is mediated by the action of dAdo and dGuo, generated by ectonucleotidases outside the cell from the added compounds dAMP and dGMP, as charged compounds cannot enter the cells without dedicated transporters. In fact, the same effect on mtDNA was observed when adding dGuo alone to DGUOK mutant cells [92].

The first in vivo evidence further supporting the efficacy of this strategy was obtained in a TK2 p.H126N knock in model that recapitulates some clinical features of the disease and have a median survival of around 14 days [171]. TK2 catalyses the first phosphorylation of the pyrimidine $\mathrm{dNs}$, dThd and dCtd. As a consequence of TK2 dysfunction, TK2 mutant mice present a reduction in mitochondrial dTTP and dCTP, leading to mtDNA depletion [171]. TK2 deficiency, in its most severe form, causes a fatal myopathic disease in early infancy [78]. There is a considerable variability in the clinical presentation, with mtDNA depletion associated with the most severe cases and multiple mtDNA deletions being more common in milder and adult cases [172], although the clinical severity does not correlate with the residual TK2 activity [173].

Treatment of the p.H126N knock in mice with dTMP and dCMP showed delayed disease onset, improved biochemical abnormalities, increased levels of mtDNA and doubled life span, which constituted the first evidence that this therapy could be effective in patients [174] and encouraged the first compassionate treatment of patients with TK2 deficiency. Further studies demonstrated, as previously showed in vitro with DGUOK mutants, that the active compounds are the unphosphorylated molecules dThd and dCtd, rather than the charged nucleotides dTMP and dCMP, which cannot enter the cells. Knock in mice 
treated with dThd and dCtd experienced the same effect on survival and other molecular variables as those observed when treated with the monophosphates [175]. These results were replicated in a TK2 knockout model of the disease [112,176]. Thus, the therapeutic effect occurs regardless of the presence of any residual TK2 activity, should be mediated by the parallel cytosolic salvage enzymes TK1 and dCK and is limited by age-dependent factors that may account for the apparent loss of effect in older animals [112,177].

The enzyme TK2 catalyses the phosphorylation of dThd and dCtd within mitochondria, resulting in the production of the corresponding monophosphates dTMP and dCMP (Figure 1). The mechanism accounting for the effect of dThd and dCtd in the aforementioned animal models is not obvious because these lack TK2 activity, so they still should be unable to phosphorylate these administered compounds with their dysfunctional TK2 enzyme. The biochemical reason accounting for this effect should be mediated by the cytosolic enzymes TK1 (that phosphorylates dThd) and dCK (that phosphorylates dCtd). In untreated animals, endogenous dThd and dCtd concentrations would not suffice to compensate for TK2 deficiency. However, high doses of dThd and dCtd administered to the animals may enhance the cytosolic salvage pathway through two overlapping mechanisms: (1) increased substrates will increase the saturation of TK1 and dCK, thus enhancing their catalytic activity; and (2) increased substrates will also displace the thermodynamics equilibrium of the cytosolic deoxypyrimidine salvage pathway, favouring the reactions towards the phosphorylated species. Once phosphorylated, they can enter mitochondria, bypassing the defective TK2 step (Figure 1). This can be considered a "substrate enhancement therapy" as named in the original report [175].

Therapy with dThd and dCtd was initiated under compassionate use in an initial cohort of 16 paediatric and adult patients from five different countries $(400 \mathrm{mg} / \mathrm{kg} / \mathrm{day}$ of each $\mathrm{dN}$ in most patients, lower doses in a few patients), and the results of the follow-up of this cohort showed that the treatment dramatically changed the course of the disease [178]. The subgroup of five treated patients with early onset and severe disease were alive at the time of the report, after several months/years of treatment, while in the untreated historical control group with early onset severe myopathy, only $27 \%$ of patients survived beyond 2 years after diagnosis [78]. Motor function and other clinical measures stabilized or improved in all treated patients [178]. Importantly, the treatment was not associated with serious adverse effects and although it provoked diarrhoea in some patients, this in no case required withdrawal of treatment. Mild elevation of transaminases was observed in two patients belonging to an expanded cohort, which normalized when the treatment was discontinued [178]. A study focused on the effect of $\mathrm{dCtd} / \mathrm{dThd}$ on the respiratory function has recently been published, revealing improvement in several endpoints and a decreased number of respiratory infections [179]. Some clinical trials are currently assessing the safety and efficacy of the treatment with $\mathrm{dCtd} / \mathrm{dThd}$ in TK2 deficiency (see Table 2). The existence of good clinical endpoints, as well as good biochemical biomarkers of the response to the treatment [180], will facilitate the evaluation of the results.

There is preclinical evidence obtained in vitro that this strategy enhances mtDNA replication in other diseases caused by anabolic defects in dNTP metabolism. Several studies have confirmed this result in DGUOK cells [92,170,181] as well as in cells with mutations in $R R M 2 B$, encoding the p53R2 subunit of the de novo enzyme ribonucleotide reductase [182]. In the case of MNGIE, which is caused by mutations in TYMP, encoding the catabolic enzyme TP, it has been suggested that the treatment with dCtd could also be considered, because mtDNA depletion seems to be the consequence of secondary dCTP depletion as a consequence of dThd excess [87].

Interestingly, similar positive effects of $\mathrm{dN}$ supplementation on mtDNA replication have been observed in vitro and in vivo for mutations in genes not directly related with dNTP metabolism, such as POLG and MPV17 [110,111,181]. This is particularly significant for the case of patients with mutations in POLG, as this is the most prevalent gene among all those causing MDDS. In this particular case, it was verified that $\mathrm{dN}$ supplementation (which changes dNTP composition) does not induce somatic mutations in de novo 
synthesized mtDNA [110]. The biochemical mechanism accounting for the $\mathrm{dN}$-induced enhancement of mtDNA replication, even with normal dNTP anabolism, may be mediated by an enhanced activity of polymerase gamma, which is activated by increased substrate (dNTP) availability.

In any case, further in vivo preclinical testing is needed to confirm the efficacy of dNs as a treatment for MDDS other than TK2 deficiency. Some existing animal models are not adequate for this purpose. For example, the mutator Polg knock in mouse has a dysfunctional proof-reading exonuclease activity and does not present mtDNA depletion [183], and it is thus not a good model to test whether $\mathrm{dN}$ administration enhances the polymerase activity of this enzyme. A recently generated PolgA449T/A449T mouse [184] (equivalent to the frequent A467T POLG mutation in patients) could be a more adequate model to test this therapy, although its phenotype is also limited (mainly molecular alterations).

\subsection{Gene Therapy}

In contrast to many of the above discussed treatments, gene therapy has been investigated for some forms of MDDS, only at the preclinical level. The most frequently used tool for gene delivery has been the adenoassociated virus (AAV) vectors. AAV are preferably used over other viral vectors because of the low risk of random insertion into nuclear genome as they are episomic, and because of their long-term persistence in cells [185]. However, the lack of genome integration results in a reduction in the transgene copy number because of the dilution effect in proliferating tissues. Another disadvantage of this strategy is the limited length of the cloned gene (less than $4.7 \mathrm{~kb}$ ) and the difficulty to target some of the tissues affected in MDDS.

The first preclinical study of gene therapy for a MDDS was conducted in 2005, using a knockout murine model of the myopathy caused by mutations in SLC24A4, encoding the heart/muscle isoform of the mitochondrial adenine nucleotide translocator (ANT1). AVV vectors carrying the wild-type version of Slc25A4 were generated. After some in vitro tests showing the effects of AAV transduction on mutant myoblasts obtained from the knockout mice, the vectors were injected in the skeletal muscle of neonatal mice, which increased Ant 1 expression and partially reverted the OXPHOS dysfunction, as assessed by histochemical and immunohistochemical methods [186].

$\mathrm{AAV}$-mediated gene therapy has been also tested in a model of the hepatocerebral form of MDDS caused by mutations in MPV17. This study faced some difficulties derived from the frequently observed fact that genetically modified mice do not fully recapitulate the disease they are intended to model. Although the Mpv17 knockout mouse shows many molecular features that recapitulate those observed in the human disease (the most relevant one being mtDNA depletion in the liver), the mice fail to develop any functional phenotype other than late-onset kidney dysfunction [187]. However, the authors successfully induced a phenotype resembling the hepatic dysfunction observed in patients, by feeding the animals a ketogenic diet. Under these conditions, Mpv17 knockout mice developed severe liver cirrhosis and liver failure after a few weeks. The authors treated Mpv17 knockout mice with AAV2/8 carrying the correct human coding sequence of MPV17 by intravenous injection, and the treatment rescued mtDNA levels and OXPHOS function, and prevented the liver phenotype induced by the ketogenic diet [188].

Gene therapy has been studied for MNGIE. For this disease, targeting a specific tissue is not the main objective because, as previously mentioned, the pursued effect is to clear toxic nucleosides on a systemic level. Whatever organ or cells accessible to the blood stream may be a good target to transduce the clearing enzyme TP. As indicated for the murine Mpv17 knockout model, the one available model for MNGIE (the double knockout for Tymp and Upp1) only recapitulates the biochemical imbalances of the disease [90].

Two different strategies have been tested. The first one targeted the hematopoietic tissue, which is one of the richest sources of TP in humans (but not in mice) using lentiviral vectors. This approach demonstrated a reduction in dThd and dUrd levels observed in the animal model to barely detectable levels [189]. The effect was sustained over the 
whole life of the animals [190]. An additional study provided evidence that this treatment results in phenotypic correction beyond the biochemical homeostasis restoration [191]. Importantly, integrational oncogenesis or the clonal expansion of the transduced cells was not observed [191].

However, this strategy was associated with increased mortality of the animals, most likely owing to the aggressive conditioning of recipient mice $[190,191]$. Therefore, a second strategy targeting the liver (again, a highly TP-expressing tissue in humans, but not in mice) with AAV vectors was tested, showing a long-term sustained and very efficient correction of the biochemical imbalance associated with the disease with only a mild dilution effect $[192,193]$. The comparison of different promoters showed that the one of the alpha-1-antitrypsin gene provided the best efficacy as compared to other liver or constitutive promoters [194]. Recently, the use of an enhanced animal model showed that this treatment also has a therapeutic effect on the neuromotor function of the mice [195].

All gene therapy approaches discussed above have shown very promising results. Unfortunately, there are several big steps to take before they can be translated to patients. One of the main limitations is the amount of vector needed for transduction in humans. In the case of the AAV vectors targeting the liver, we also need to consider the fact that the transduction efficiency is lower in humans as compared to that observed in mice [196-198]. The production of clinical grade vectors is expensive. Thus, the cost of producing vectors for the first preclinical regulatory safety studies and subsequent clinical trials to test the gene therapy treatments will require considerable investments that sometimes are hard to gather for rare diseases like MDDS. However, the potential societal benefits derived from the implementation of gene therapy for one or more forms of MDDS are beyond any doubt, which should encourage stakeholders to pursue this objective.

\subsection{Improving Mitochondrial Shape and Other Approaches}

As some MDDS are caused by mutations in factors regulating mitochondrial dynamics, strategies aimed at restoring these processes and improving mitochondrial shape have been considered. Moderate overexpression of OPA1 is found to regulate the organization of respiratory complexes in mice with mutations in genes not related to MDDS [199]. Additionally, the inhibition of OMA1, which cleaves and degrades OPA1 under stress conditions, resulted in the rescue of mtDNA levels (but not respiratory function) in a non-related MDDS gene KO mouse [200]. Although these results show promising results, they should be tested in MDDS models.

MDDS caused by mutations in MFN2 can be potentially treated with a strategy that uses a small mitofusin agonist that activates MFN2, thus promoting mitochondrial fusion [201]. This work showed that axonal mitochondrial trafficking, which is dysfunctional in Charcot-Marie-Tooth disease, was restored in treated MFN2 p.Thr105Met mutant mice.

Another strategy targeting mitochondrial shape consists of the use of Szeto-Schiller (SS) peptides. SS peptides enter mitochondria and bind cardiolipin, a lipid of the inner mitochondrial membrane that regulates respiratory chain complexes and cristae structures. Elamipretide (also called MTP-131) is an SS peptide that has been found to be able to correct mitochondrial ultrastructure [202,203]. Again, this strategy has not yet been tested in MDDS but previous results suggest that it may constitute a potential approach for some forms of these syndromes.

A yeast-based screening assay of 1500 chemical compounds has identified clofilium tyosilate (CLO) to be useful to correct mtDNA instability in POLG mutants [204]. This compound was re-evaluated in human fibroblasts derived from one patient carrying POLG mutations, demonstrating its ability to rescue mtDNA levels [204]. Further studies with this compound have been conducted using zebrafish as a model, showing an increase in mtDNA levels either in mutant and wild-type individuals, as well as the restoration of complex I activity. Moreover, it improved the cardio-skeletal effects of POLG deficiency. Although it is known that CLO is an antiarrhythmic acting as a potassium channel blocker, its mechanism of action in rescuing mtDNA levels is not known [205]. 


\section{Prospects and Specific Barriers}

Many therapeutic approaches have been suggested or applied to treat mitochondrial diseases in general, and more specifically for MDDS. The complexity and variability of these disorders makes it difficult in many cases to definitely conclude whether they have demonstrated substantial efficacy. Those in clinical trial phases are expected to reach this milestone at the specific expected time points defined in the trial.

Currently, MDDS have very limited options for therapy, although significant progresses have been achieved in recent years and the situation is significantly different now than it was ten years ago. Some aggressive treatments, such as liver transplantation for mutations in DGUOK, POLG, MPV17 and TYMP, or AHSCT for patients with mutations in $T Y M P$, have shown variable success and to date are the only available choices for patients that, without treatment, could face a fatal outcome. One of the potential alternatives for some of these forms of MDDS is the implementation of gene therapy approaches. As indicated at the end of the corresponding Section 4.6, the investment needed for the mandatory preclinical and clinical investigations complying with the requirements of the regulatory agencies for gene therapy trials is an important barrier. However, it should be largely compensated by the potential benefits that these therapies will provide if they are demonstrated to be effective and safe for patients.

The potential improvement that may constitute the $\mathrm{dN}$-treatment if it is finally approved for TK2 deficiency should be also underlined. Robust clinical results show that this therapy changes the clinical course of the disease, at least for paediatric patients [178]. Importantly, several preclinical studies at different in vitro and in vivo stages indicate that this approach may be also effective, for MDDS forms caused by mutations in POLG, MPV17, DGUOK or others $[92,110,111,181,182,206]$. However, the main barrier for this strategy is the poor availability of the orally administered dNs, especially the purines dAdo and dGuo. Further research to overcome this important difficulty should be conducted, including the inhibition of the fast catabolism of these compounds by several means, or exploring alternate administration routes that bypass or avoid the degradation of these molecules.

The special importance of the availability of in vivo models to test these therapies should be also noted. Experimental evidence supporting the efficacy of some of the experimental approaches discussed above has only been obtained in vitro, and we should be very cautious before using these approaches in patients, unless their efficacy is additionally confirmed in vivo using animal models. There are several genetically modified mouse strains that aim to model these diseases (reviewed by $[207,208]$ as well as some other vertebrate models $[206,209])$. Some of the murine models recapitulate, at least partially, the clinical phenotype of the diseases $[171,176,187,210-212]$, but in some other cases, the phenotype is barely biochemical or molecular, with no or little effect on the functional life of the animals $[90,184]$. Sometimes, the models can be stressed to show enhanced phenotypes that result as useful to show the efficacy of the experimental therapies $[188,195,213]$. In any case, testing in these models those treatments that have shown promising results in cell culture or other in vitro models should be encouraged in order to accelerate the implementation of clinical programs for them.

Lastly, there is a general barrier that contributes to complicating the advance of research and implementation of therapies for MDDS. All these are very rare disorders, with prevalences ranging from 1:51,000 for the Alpers-Huttenlocher syndrome [214] to ultrarare diseases such as MNGIE with around one case per 10 million people ([215] an unpublished personal estimate), or even less for other MDDS forms. This often makes it difficult to reach a correct diagnosis because of unawareness and hinders the recruitment of patients for the clinical investigation of new treatments. The rarity and severity of many MDDS also complicates the design of the clinical trials, and the clinical heterogeneity characteristic of MDDS also challenges the completion of informative clinical history studies, needed in some cases to substitute the absence of untreated control groups in clinical trials. 
In recent years, research on rare diseases has gained increasing interest and resources, and this has flourished in a diversity of emerging therapies that could soon be available for patients. However, the clinical implementation of these therapies will ultimately depend on our ability to drive stakeholders' attention toward the huge societal impact that these treatments would have. To strengthen and build up new wide and solid collaborative networks, including with basic and clinic researchers, will surely contribute to minimize many of the barriers challenging the development of future therapies for MDDS and other rare diseases.

\section{Conclusions}

The potential therapy choices for patients with mtDNA maintenance disorders have significantly increased in the last ten years. The data collected in this review indicate that there are currently nine active interventional clinical trials for seven different treatments, recruiting patients with mutations in five different genes (POLG, TYMP, TK2, OPA1 and SUCLA2). This constitutes a good record if we consider that MDDS are very rare disorders. Moreover, there is growing optimism in the possibility of expanding the potential therapy options for these disorders due to the large number of preclinical data that researchers in the field have gathered in recent years. This is a growing group of diseases, with mutations in new genes causing MDDS found almost every year. However, they are well delimited by the presence of one or more of the hallmarks that define this group of disorders (i.e., somatic alterations of mtDNA such as depletion, multiple deletions and point mutations). Many of the genes associated with MDDS encode proteins belonging to the mtDNA replication machinery, dNTP metabolism or mitochondrial dynamics, and these biological processes are the subject of in-depth investigation by the scientific community working in the mitochondrial field. Without a doubt, the combination of relatively well-known pathomechanisms of these disorders and an increasing knowledge of the basic biochemical and molecular processes involved in mtDNA replication has contributed to the implementation of many novel therapy approaches for MDDS. Our efforts should now be dedicated to maintaining and further improving our knowledge in this field, thus generating new approaches and refining those already under preclinical and clinical investigation, and to overcome the aforementioned barriers hindering their final implementation into medical practice.

Author Contributions: J.R. and R.M. designed the structure of the review and decided its main scope. J.R. wrote the first version of the manuscript. F.V.-J., D.M.-G., M.M.-B., M.J.M., E.G.-A., J.T.-T. and Y.C. contributed to the critical revision of the manuscript and suggested additional improvements. R.M. made the final editions to the final version of the manuscript. All authors have read and agreed to the published version of the manuscript.

Funding: This work has been supported by the Spanish Instituto de Salud Carlos III (Grants PMP15/00025 and PI18/01574 to R.M., co-funded with E.R.D.F.) and by the Catalan Generalitat de Catalunya (PERIS program, SLT002/16/00370 to J.T. and FI-AGAUR program 2018FI_B_01115 to F.V.).

Institutional Review Board Statement: Not applicable.

Informed Consent Statement: Not applicable.

Data Availability Statement: Not applicable.

Conflicts of Interest: R.M., J.T. and Y.C. report grants and non-financial support from Modis Therapeutics, personal fees and other from Modis Therapeutics, outside the submitted work; R.M. has a patent "Deoxynucleoside therapy for diseases caused by unbalanced nucleotide pools including mitochondrial DNA depletion syndromes" (PCT/US16/038110) with royalties paid to Modis Therapeutics; R.M., Y.C. and J.T. have a patent “Treatment of mitochondrial diseases" (PCT/EP2016/062636) with royalties paid to Modis Therapeutics.

\section{References}

1. Schon, E.A.; DiMauro, S.; Hirano, M. Human mitochondrial DNA: Roles of inherited and somatic mutations. Nat. Rev. Genet. 2012, 13, 878-890. [CrossRef] 
2. McBride, H.M.; Neuspiel, M.; Wasiak, S. Mitochondria: More than Just a Powerhouse. Curr. Biol. 2006, 16, R551-R560. [CrossRef]

3. Hajnóczky, G.; Csordás, G.; Das, S.; Garcia-Perez, C.; Saotome, M.; Roy, S.S.; Yi, M. Mitochondrial calcium signalling and cell death: Approaches for assessing the role of mitochondrial $\mathrm{Ca}^{2+}$ uptake in apoptosis. Cell Calcium 2006, 40, 553-560. [CrossRef]

4. Breda, C.N.D.S.; Davanzo, G.G.; Basso, P.J.; Câmara, N.O.S.; Moraes-Vieira, P.M.M. Mitochondria as central hub of the immune system. Redox Biol. 2019, 26, 101255. [CrossRef] [PubMed]

5. Gorman, G.S.; Chinnery, P.F.; DiMauro, S.; Hirano, M.; Koga, Y.; McFarland, R.; Suomalainen, A.; Thorburn, D.R.; Zeviani, M.; Turnbull, D.M. Mitochondrial diseases. Nat. Rev. Dis. Primers 2016, 2, 16080. [CrossRef] [PubMed]

6. Sagan, L. On the origin of mitosing cells. J. Theor. Biol. 1967, 14, 225-274, IN1-IN6. [CrossRef]

7. Gray, M.W. Lynn Margulis and the endosymbiont hypothesis: 50 years later. Mol. Biol. Cell 2017, 28, 1285-1287. [CrossRef]

8. García-Rodríguez, L.J. Appendix Basic Properties of Mitochondria. Echinoderms Part B 2007, 80, 809-812. [CrossRef]

9. Rath, S.; Sharma, R.; Gupta, R.; Ast, T.; Chan, C.; Durham, T.J.; Goodman, R.P.; Grabarek, Z.; Haas, M.E.; Hung, W.H.W.; et al. MitoCarta3.0: An updated mitochondrial proteome now with sub-organelle localization and pathway annotations. Nucleic Acids Res. 2021, 49, D1541-D1547. [CrossRef]

10. DiMauro, S. Mitochondrial DNA Medicine. Biosci. Rep. 2007, 27, 5-9. [CrossRef]

11. Koopman, W.J.; Willems, P.H.; Smeitink, J.A. Monogenic Mitochondrial Disorders. N. Engl. J. Med. 2012, 366, 1132-1141. [CrossRef]

12. Ahmed, N.; Ronchi, D.; Comi, G.P. Genes and Pathways Involved in Adult Onset Disorders Featuring Muscle Mitochondrial DNA Instability. Int. J. Mol. Sci. 2015, 16, 18054-18076. [CrossRef] [PubMed]

13. Suomalainen, A.; Isohanni, P. Mitochondrial DNA depletion syndromes-Many genes, common mechanisms. Neuromuscul. Disord. 2010, 20, 429-437. [CrossRef] [PubMed]

14. El-Hattab, A.W.; Craigen, W.J.; Wong, L.J.C.; Scaglia, F. Mitochondrial DNA maintenance defects overview. In Gene Reviews ${ }^{\circledR}$; Adam, M.P., Ardinger, H.H., Pagon, R.A., Wallace, S.E., Bean, L.J.H., Mirzaa, G., Amemiya, A., Eds.; University of Washington: Seattle, WA, USA, 2018.

15. Garone, C.; Tadesse, S.; Hirano, M. Clinical and genetic spectrum of mitochondrial neurogastrointestinal encephalomyopathy. Brain 2011, 134, 3326-3332. [CrossRef]

16. Van Goethem, G.; Dermaut, B.; Lofgren, A.; Martin, J.J.; van Broeckhoven, C. Mutation of POLG is associated with progressive external ophthalmoplegia characterized by mtDNA deletions. Nat. Genet. 2001, 28, 211-212. [CrossRef]

17. Longley, M.J.; Clark, S.; Yu Wai Man, C.; Hudson, G.; Durham, S.E.; Taylor, R.W.; Nightingale, S.; Turnbull, D.M.; Copeland, W.C.; Chinnery, P.F. Mutant POLG2 disrupts DNA polymerase gamma subunits and causes progressive external ophthalmoplegia. Am. J. Hum. Genet. 2006, 78, 1026-1034. [CrossRef]

18. Spelbrink, J.N.; Li, F.-Y.; Tiranti, V.; Nikali, K.; Yuan, Q.-P.; Tariq, M.; Wanrooij, S.; Garrido, N.; Comi, G.; Morandi, L.; et al. Human mitochondrial DNA deletions associated with mutations in the gene encoding Twinkle, a phage T7 gene 4-like protein localized in mitochondria. Nat. Genet. 2001, 28, 223-231. [CrossRef] [PubMed]

19. Kornblum, C.; Nicholls, T.J.; Haack, T.B.; Scholer, S.; Peeva, V.; Danhauser, K.; Hallmann, K.; Zsurka, G.; Rorbach, J.; Iuso, A.; et al. Loss-of-function mutations in MGME1 impair mtDNA replication and cause multisystemic mitochondrial disease. Nat. Genet. 2013, 45, 214-219. [CrossRef]

20. Ronchi, D.; di Fonzo, A.; Lin, W.; Bordoni, A.; Liu, C.; Fassone, E.; Pagliarani, S.; Rizzuti, M.; Zheng, L.; Filosto, M.; et al. Mutations in DNA2 Link Progressive Myopathy to Mitochondrial DNA Instability. Am. J. Hum. Genet. 2013, 92, 293-300. [CrossRef]

21. Reyes, A.; Melchionda, L.; Nasca, A.; Carrara, F.; Lamantea, E.; Zanolini, A.; Lamperti, C.; Fang, M.; Zhang, J.; Ronchi, D.; et al. RNASEH1 Mutations Impair mtDNA Replication and Cause Adult-Onset Mitochondrial Encephalomyopathy. Am. J. Hum. Genet. 2015, 97, 186-193. [CrossRef]

22. Stiles, A.R.; Simon, M.; Stover, A.; Eftekharian, S.; Khanlou, N.; Wang, H.L.; Magaki, S.; Lee, H.; Partynski, K.; Dorrani, N.; et al. Mutations in TFAM, encoding mitochondrial transcription factor A, cause neonatal liver failure associated with mtDNA depletion. Mol. Genet. Metab. 2016, 119, 91-99. [CrossRef]

23. Martin, C.A.; Sarlos, K.; Logan, C.V.; Thakur, R.S.; Parry, D.A.; Bizard, A.H.; Leitch, A.; Cleal, L.; Ali, N.S.; Al-Owain, M.A.; et al. Mutations in TOP3A Cause a Bloom Syndrome-Like Disorder. Am. J. Hum. Genet. 2018, 103, 221-231. [CrossRef]

24. Jurkute, N.; Leu, C.; Pogoda, H.; Arno, G.; Robson, A.G.; Nürnberg, G.; Altmüller, J.; Thiele, H.; Motameny, S.; Toliat, M.R.; et al. SSBP1 mutations in dominant optic atrophy with variable retinal degeneration. Ann. Neurol. 2019, 86, 368-383. [CrossRef]

25. Bonora, E.; Chakrabarty, S.; Kellaris, G.; Tsutsumi, M.; Bianco, F.; Bergamini, C.; Ullah, F.; Isidori, F.; Liparulo, I.; Diquigiovanni, C.; et al. Biallelic variants in LIG3 cause a novel mitochondrial neurogastrointestinal encephalomyopathy. Brain 2021, awab056. [CrossRef] [PubMed]

26. Nishino, I.; Spinazzola, A.; Hirano, M. Thymidine Phosphorylase Gene Mutations in MNGIE, a Human Mitochondrial Disorder. Science 1999, 283, 689-692. [CrossRef]

27. Saada, A.; Shaag, A.; Mandel, H.; Nevo, Y.; Eriksson, S.; Elpeleg, O. Mutant mitochondrial thymidine kinase in mitochondrial DNA depletion myopathy. Nat. Genet. 2001, 29, 342-344. [CrossRef]

28. Mandel, H.; Szargel, R.; Labay, V.; Elpeleg, O.; Saada, A.; Shalata, A.; Anbinder, Y.; Berkowitz, D.; Hartman, C.; Barak, M.; et al. The deoxyguanosine kinase gene is mutated in individuals with depleted hepatocerebral mitochondrial DNA. Nat. Genet. 2001, 29, 337-341. [CrossRef] [PubMed] 
29. Bourdon, A.; Minai, L.; Serre, V.; Jais, J.P.; Sarzi, E.; Aubert, S.; Chretien, D.; de Lonlay, P.; Paquis-Flucklinger, V.; Arakawa, $\mathrm{H}$.; et al. Mutation of RRM2B, encoding p53-controlled ribonucleotide reductase (p53R2), causes severe mitochondrial DNA depletion. Nat. Genet. 2007, 39, 776-780. [CrossRef] [PubMed]

30. Hudson, G.; Amati-Bonneau, P.; Blakely, E.L.; Stewart, J.D.; He, L.; Schaefer, A.M.; Griffiths, P.G.; Ahlqvist, K.; Suomalainen, A.; Reynier, P.; et al. Mutation of OPA1 causes dominant optic atrophy with external ophthalmoplegia, ataxia, deafness and multiple mitochondrial DNA deletions: A novel disorder of mtDNA maintenance. Brain 2008, 131, 329-337. [CrossRef]

31. Rouzier, C.; Bannwarth, S.; Chaussenot, A.; Chevrollier, A.; Verschueren, A.; Bonello-Palot, N.; Fragaki, K.; Cano, A.; Pouget, J.; Pellissier, J.F.; et al. The MFN2 gene is re-sponsible for mitochondrial DNA instability and optic atrophy 'plus' phenotype. Brain 2012, 135, 23-34. [CrossRef]

32. Wedding, I.M.; Koht, J.; Tran, G.T.; Misceo, D.; Selmer, K.K.; Holmgren, A.; Frengen, E.; Bindoff, L.; Tallaksen, C.M.; Tzoulis, C. Spastic paraplegia type 7 is associated with multiple mitochondrial DNA deletions. PLoS ONE 2014, 9, e86340. [CrossRef]

33. Gorman, G.; Pfeffer, G.; Griffin, H.R.; Blakely, E.L.; Kurzawa-Akanbi, M.; Gabriel, J.; Sitarz, K.; Roberts, M.; Schoser, B.; Pyle, A.; et al. Clonal Expansion of Secondary Mitochondrial DNA Deletions Associated with Spinocerebellar Ataxia Type. JAMA Neurol. 2015, 72, 106-111. [CrossRef]

34. Nasca, A.; Scotton, C.; Zaharieva, I.; Neri, M.; Selvatici, R.; Magnusson, O.T.; Gal, A.; Weaver, D.; Rossi, R.; Armaroli, A.; et al. Recessive mutations in MSTO1 cause mitochondrial dynamics impairment, leading to myopathy and ataxia. Hum. Mutat. 2017, 38, 970-977. [CrossRef] [PubMed]

35. Russell, B.E.; Whaley, K.G.; Bove, K.E.; Labilloy, A.; Lombardo, R.C.; Hopkin, R.J.; Leslie, N.D.; Prada, C.; Assouline, Z.; Barcia, G.; et al. Expanding and Underscoring the Hepato-Encephalopathic Phenotype of QIL1/MIC13. Hepatology 2019, 70, 1066-1070. [CrossRef]

36. Kaukonen, J.; Juselius, J.K.; Tiranti, V.; Kyttälä, A.; Zeviani, M.; Comi, G.; Keränen, S.; Peltonen, L.; Suomalainen-Wartiovaara, A Role of Adenine Nucleotide Translocator 1 in mtDNA Maintenance. Science 2000, 289, 782-785. [CrossRef] [PubMed]

37. Spinazzola, A.; Viscomi, C.; Fernandez-Vizarra, E.; Carrara, F.; D'Adamo, P.; Calvo, S.; Marsano, R.M.; Donnini, C.; Weiher, H.; Strisciuglio, P.; et al. MPV17 encodes an inner mitochondrial membrane protein and is mutated in infantile hepatic mitochondrial DNA depletion. Nat. Genet. 2006, 38, 570-575. [CrossRef] [PubMed]

38. Boczonadi, V.; King, M.S.; Smith, A.C.; Oláhová, M.; Bansagi, B.; Roos, A.; Eyassu, F.; Borchers, C.; Ramesh, V.; Lochmuller, H.; et al. Mitochondrial oxodicarboxylate carrier deficiency is associated with mitochondrial DNA depletion and spinal muscular atrophy-like disease. Genet. Med. 2018, 20, 1224-1235. [CrossRef]

39. Punzi, G.; Porcelli, V.; Ruggiu, M.; Hossain, F.; Menga, A.; Scarcia, P.; Castegna, A.; Gorgoglione, R.; Pierri, C.L.; Laera, L.; et al. SLC25A10 biallelic mutations in intractable epileptic encephalopathy with complex I deficiency. Hum. Mol. Genet. 2018, 27, 499-504. [CrossRef]

40. Elpeleg, O.; Miller, C.; Hershkovitz, E.; Bitner-Glindzicz, M.; Bondi-Rubinstein, G.; Rahman, S.; Pagnamenta, A.; Eshhar, S.; Saada, A. Deficiency of the ADP-forming succinyl-CoA synthase activity is associated with encephalomyopathy and mitochondrial DNA depletion. Am. J. Hum. Genet. 2005, 76, 1081-1086. [CrossRef]

41. Ostergaard, E.; Christensen, E.; Kristensen, E.; Mogensen, B.; Duno, M.; Shoubridge, E.A.; Wibrand, F. Deficiency of the alpha subunit of succinate-coenzyme A ligase causes fatal infantile lactic acidosis with mitochondrial DNA depletion. Am. J. Hum. Genet. 2007, 81, 383-387. [CrossRef]

42. Calvo, S.E.; Compton, A.G.; Hershman, S.G.; Lim, S.C.; Lieber, D.S.; Tucker, E.J.; Laskowski, A.; Garone, C.; Liu, S.; Jaffe, D.B.; et al. Molecular diagnosis of infantile mitochondrial disease with targeted next-generation sequencing. Sci. Transl. Med. 2012, 4, 118ra10. [CrossRef] [PubMed]

43. Di Fonzo, A.; Ronchi, D.; Lodi, T.; Fassone, E.; Tigano, M.; Lamperti, C.; Corti, S.; Bordoni, A.; Fortunato, F.; Nizzardo, M.; et al. The Mitochondrial Disulfide Relay System Protein GFER Is Mutated in Autosomal-Recessive Myopathy with Cataract and Combined Respiratory-Chain Deficiency. Am. J. Hum. Genet. 2009, 84, 594-604. [CrossRef] [PubMed]

44. Besse, A.; Wu, P.; Bruni, F.; Donti, T.; Graham, B.H.; Craigen, W.J.; McFarland, R.; Moretti, P.; Lalani, S.; Scott, K.L.; et al. The GABA transaminase, ABAT, is essential for mitochondrial nucleoside metabolism. Cell Metab. 2015, 21, 417-427. [CrossRef] [PubMed]

45. Bonnen, P.E.; Yarham, J.W.; Besse, A.; Wu, P.; Faqeih, E.A.; Al-Asmari, A.M.; Saleh, M.A.; Eyaid, W.; Hadeel, A.; He, L.; et al. Mutations in FBXL4 cause mitochondrial encephalopathy and a disorder of mitochondrial DNA maintenance. Am. J. Hum. Genet. 2013, 93, 471-481. [CrossRef]

46. Garone, C.; D’Souza, A.R.; Dallabona, C.; Lodi, T.; Rebelo-Guiomar, P.; Rorbach, J.; Donati, M.A.; Procopio, E.; Montomoli, M.; Guerrini, R.; et al. Defective mitochondrial rRNA methyltransferase MRM2 causes MELAS-like clinical syndrome. Hum. Mol. Genet. 2017, 26, 4257-4266. [CrossRef] [PubMed]

47. Feichtinger, R.G.; Olahova, M.; Kishita, Y.; Garone, C.; Kremer, L.S.; Yagi, M.; Uchiumi, T.; Jourdain, A.A.; Thompson, K.; D’Souza, A.R.; et al. Biallelic C1QBP Mutations Cause Severe Neonatal-, Childhood-, or Later-Onset Cardiomyopathy Associated with Combined Respiratory-Chain Deficiencies. Am. J. Hum. Genet. 2017, 101, 525-538. [CrossRef] [PubMed]

48. Oliveira, M.T.; Pontes, C.D.B.; Ciesielski, G.L. Roles of the mitochondrial replisome in mitochondrial DNA deletion formation. Genet. Mol. Biol. 2020, 43, e20190069. [CrossRef]

49. Young, M.J.; Copeland, W.C. Human mitochondrial DNA replication machinery and disease. Curr. Opin. Genet. Dev. 2016, 38, 52-62. [CrossRef] 
50. Lecrenier, N.; van der Bruggen, P.; Foury, F. Mitochondrial DNA polymerases from yeast to man: A new family of polymerases. Gene 1997, 185, 147-152. [CrossRef]

51. Rahman, S.; Copeland, W.C. POLG-related disorders and their neurological manifestations. Nat. Rev. Neurol. 2019, 15, 40-52. [CrossRef]

52. Del Bo, R.; Bordoni, A.; Sciacco, M.; di Fonzo, A.; Galbiati, S.; Crimi, M.; Bresolin, N.; Comi, G.P. Remarkable infidelity of polymerase $\gamma \mathrm{A}$ associated with mutations in POLG1 exonuclease domain. Neurology 2003, 61, 903-908. [CrossRef]

53. Hikmat, O.; Naess, K.; Engvall, M.; Klingenberg, C.; Rasmussen, M.; Tallaksen, C.M.; Brodtkorb, E.; Ostergaard, E.; Coo, I.F.M.; Pias-Peleteiro, L.; et al. Simplifying the clinical classification of polymerase gamma (POLG) disease based on age of onset; studies using a cohort of 155 cases. J. Inherit. Metab. Dis. 2020, 43, 726-736. [CrossRef]

54. Young, M.J.; Longley, M.J.; Li, F.-Y.; Kasiviswanathan, R.; Wong, L.-J.; Copeland, W.C. Biochemical analysis of human POLG2 variants associated with mitochondrial disease. Hum. Mol. Genet. 2011, 20, 3052-3066. [CrossRef] [PubMed]

55. Varma, H.; Faust, P.L.; Iglesias, A.D.; Lagana, S.M.; Wou, K.; Hirano, M.; DiMauro, S.; Mansukani, M.M.; Hoff, K.E.; Nagy, P.L.; et al. Whole exome sequencing identifies a homozygous POLG2 missense variant in an infant with fulminant hepatic failure and mitochondrial DNA depletion. Eur. J. Med. Genet. 2016, 59, 540-545. [CrossRef]

56. Hoff, K.E.; DeBalsi, K.L.; Sanchez-Quintero, M.J.; Longley, M.J.; Hirano, M.; Naini, A.B.; Copeland, W.C. Characterization of the human homozygous R182W POLG2 mutation in mitochondrial DNA depletion syndrome. PLoS ONE 2018, 13, e0203198. [CrossRef] [PubMed]

57. Korhonen, J.A.; Gaspari, M.; Falkenberg, M. TWINKLE Has $5^{\prime} \rightarrow 3^{\prime}$ DNA Helicase Activity and Is Specifically Stimulated by Mitochondrial Single-stranded DNA-binding Protein. J. Biol. Chem. 2003, 278, 48627-48632. [CrossRef] [PubMed]

58. Goffart, S.; Cooper, H.M.; Tyynismaa, H.; Wanrooij, S.; Suomalainen, A.; Spelbrink, J.N. Twinkle mutations associated with autosomal dominant progressive external ophthalmoplegia lead to impaired helicase function and in vivo mtDNA replication stalling. Hum. Mol. Genet. 2009, 18, 328-340. [CrossRef] [PubMed]

59. Nikali, K.; Suomalainen, A.; Saharinen, J.; Kuokkanen, M.; Spelbrink, J.N.; Lonnqvist, T.; Peltonen, L. Infantile onset spinocerebellar ataxia is caused by recessive mutations in mitochondrial proteins Twinkle and Twinky. Hum. Mol. Genet. 2005, 14, 2981-2990. [CrossRef]

60. Ruiz, M.D.; García-Martínez, A.; Corral-Juan, M.; Pérez-Álvarez, Á.I.; Plasencia, A.M.; Villamar, M.; Moreno-Pelayo, M.A.; Matilla-Dueñas, A.; Menéndez-González, M.; del Castillo, I. Perrault syndrome with neurological features in a compound heterozygote for two TWNK mutations: Overlap of TWNK-related recessive disorders. J. Transl. Med. 2019, 17, 290. [CrossRef] [PubMed]

61. Morino, H.; Pierce, S.B.; Matsuda, Y.; Walsh, T.; Ohsawa, R.; Newby, M.; Hiraki-Kamon, K.; Kuramochi, M.; Lee, M.K.; Klevit, R.E.; et al. Mutations in Twinkle primase-helicase cause Perrault syndrome with neurologic features. Neurology 2014, 83, $2054-2061$. [CrossRef]

62. Wanrooij, S.; Luoma, P.; van Goethem, G.; van Broeckhoven, C.; Suomalainen, A.; Spelbrink, J.N. Twinkle and POLG defects enhance age-dependent accumulation of mutations in the control region of mtDNA. Nucleic Acids Res. 2004, 32, 3053-3064. [CrossRef]

63. Nishigaki, Y.; Marti, R.; Copeland, W.C.; Hirano, M. Site-specific somatic mitochondrial DNA point mutations in patients with thymidine phosphorylase deficiency. J. Clin. Investig. 2003, 111, 1913-1921. [CrossRef]

64. Del Dotto, V.; Ullah, F.; di Meo, I.; Magini, P.; Gusic, M.; Maresca, A.; Caporali, L.; Palombo, F.; Tagliavini, F.; Baugh, E.H.; et al. SSBP1 mutations cause mtDNA depletion underlying a complex optic atrophy disorder. J. Clin. Investig. 2020, 130, 108-125. [CrossRef] [PubMed]

65. Nicholls, T.J.; Nadalutti, C.A.; Motori, E.; Sommerville, E.W.; Gorman, G.; Basu, S.; Hoberg, E.; Turnbull, D.M.; Chinnery, P.F.; Larsson, N.-G.; et al. Topoisomerase $3 \alpha$ Is Required for Decatenation and Segregation of Human mtDNA. Mol. Cell 2018, 69, 9-23. [CrossRef]

66. Wang, L. Mitochondrial purine and pyrimidine metabolism and beyond. Nucleosides Nucleotides Nucleic Acids 2016, 35, 578-594. [CrossRef]

67. Ferraro, P.; Nicolosi, L.; Bernardi, P.; Reichard, P.; Bianchi, V. Mitochondrial deoxynucleotide pool sizes in mouse liver and evidence for a transport mechanism for thymidine monophosphate. Proc. Natl. Acad. Sci. USA 2006, 103, 18586-18591. [CrossRef] [PubMed]

68. Pontarin, G.; Gallinaro, L.; Ferraro, P.; Reichard, P.; Bianchi, V. Origins of mitochondrial thymidine triphosphate: Dynamic relations to cytosolic pools. Proc. Natl. Acad. Sci. USA 2003, 100, 12159-12164. [CrossRef]

69. Di Noia, M.A.; Todisco, S.; Cirigliano, A.; Rinaldi, T.; Agrimi, G.; Iacobazzi, V.; Palmieri, F. The human SLC25A33 and SLC25A36 genes of solute carrier family 25 encode two mitochondrial pyrimidine nucleotide transporters. J. Biol. Chem. 2014, 289, 33137-33148. [CrossRef]

70. Floyd, S.; Favre, C.; Lasorsa, F.M.; Leahy, M.; Trigiante, G.; Stroebel, P.; Marx, A.; Loughran, G.; O'Callaghan, K.; Marobbio, C.M.; et al. The insulin-like growth factor-I-mTOR signaling pathway induces the mitochondrial pyrimidine nucleotide carrier to promote cell growth. Mol. Biol. Cell 2007, 18, 3545-3555. [CrossRef]

71. Franzolin, E.; Miazzi, C.; Frangini, M.; Palumbo, E.; Rampazzo, C.; Bianchi, V. The pyrimidine nucleotide carrier PNC1 and mitochondrial trafficking of thymidine phosphates in cultured human cells. Exp. Cell Res. 2012, 318, 2226-2236. [CrossRef] [PubMed] 
72. Shaibani, A.; Shchelochkov, O.A.; Zhang, S.; Katsonis, P.; Lichtarge, O.; Wong, L.J.; Shinawi, M. Mitochondrial neurogastrointestinal encephalopathy due to mutations in RRM2B. Arch. Neurol. 2009, 66, 1028-1032. [CrossRef]

73. Fratter, C.; Raman, P.; Alston, C.L.; Blakely, E.L.; Craig, K.; Smith, C.; Evans, J.; Seller, A.; Czermin, B.; Hanna, M.G.; et al. RRM2B mutations are frequent in familial PEO with multiple mtDNA deletions. Neurology 2011, 76, 2032-2034. [CrossRef] [PubMed]

74. Horga, A.; Pitceathly, R.D.S.; Blake, J.C.; Woodward, C.E.; Zapater, P.; Fratter, C.; Mudanohwo, E.E.; Plant, G.T.; Houlden, H.; Sweeney, M.G.; et al. Peripheral neuropathy predicts nuclear gene defect in patients with mitochondrial ophthalmoplegia. Brain 2014, 137, 3200-3212. [CrossRef]

75. Pitceathly, R.D.S.; Fassone, E.; Taanman, J.-W.; Sadowski, M.; Fratter, C.; Mudanohwo, E.E.; Woodward, C.E.; Sweeney, M.G.; Holton, J.L.; Hanna, M.G.; et al. Kearns-Sayre syndrome caused by defective R1/p53R2 assembly. J. Med. Genet. 2011, 48, 610-617. [CrossRef] [PubMed]

76. Pitceathly, R.D.S.; Smith, C.; Fratter, C.; Alston, C.L.; He, L.; Craig, K.; Blakely, E.L.; Evans, J.C.; Taylor, J.; Shabbir, Z.; et al. Adults with RRM2B-related mitochondrial disease have distinct clinical and molecular characteristics. Brain 2012, 135, 3392-3403. [CrossRef] [PubMed]

77. Tyynismaa, H.; Ylikallio, E.; Patel, M.; Molnar, M.J.; Haller, R.G.; Suomalainen, A. A heterozygous truncating mutation in RRM2B causes autosomal-dominant progressive external ophthalmoplegia with multiple mtDNA deletions. Am. J. Hum. Genet. 2009, 85, 290-295. [CrossRef] [PubMed]

78. Garone, C.; Taylor, R.W.; Nascimento, A.; Poulton, J.; Fratter, C.; Dominguez-Gonzalez, C.; Evans, J.C.; Loos, M.; Isohanni, P.; Suomalainen, A.; et al. Retrospective natural history of thymidine kinase 2 deficiency. J. Med. Genet. 2018, 55, 515-521. [CrossRef] [PubMed]

79. Caporali, L.; Bello, L.; Tagliavini, F.; La Morgia, C.; Maresca, A.; di Vito, L.; Liguori, R.; Valentino, M.L.; Cecchin, D.; Pegoraro, E.; et al. DGUOK recessive mutations in patients with $\mathrm{CPEO}$, mitochondrial myopathy, parkinsonism and mtDNA deletions. Brain 2017, 141, e3. [CrossRef]

80. Ronchi, D.; Garone, C.; Bordoni, A.; Rios, P.G.; Calvo, S.E.; Ripolone, M.; Ranieri, M.; Rizzuti, M.; Villa, L.; Magri, F.; et al. Next-generation sequencing reveals DGUOK mutations in adult patients with mitochondrial DNA multiple deletions. Brain 2012, 135, 3404-3415. [CrossRef]

81. Rampazzo, C.; Gallinaro, L.; Milanesi, E.; Frigimelica, E.; Reichard, P.; Bianchi, V. A deoxyribonucleotidase in mitochondria: Involvement in regulation of dNTP pools and possible link to genetic disease. Proc. Natl. Acad. Sci. USA 2000, 97, 8239-8244. [CrossRef]

82. Franzolin, E.; Pontarin, G.; Rampazzo, C.; Miazzi, C.; Ferraro, P.; Palumbo, E.; Reichard, P.; Bianchi, V. The deoxynucleotide triphosphohydrolase SAMHD1 is a major regulator of DNA precursor pools in mammalian cells. Proc. Natl. Acad. Sci. USA 2013, 110, 14272-14277. [CrossRef] [PubMed]

83. Requena, C.E.; Perez-Moreno, G.; Ruiz-Perez, L.M.; Vidal, A.E.; Gonzalez-Pacanowska, D. The NTP pyro-phosphatase DCTPP1 contributes to the homoeostasis and cleansing of the dNTP pool in human cells. Biochem. J. 2014, 459, 171-180. [CrossRef]

84. Martínez-Arribas, B.; Requena-Torres, C.E.; Pérez-Moreno, G.; Ruíz-Pérez, L.M.; Vidal, A.E.; González-Pacanowska, D. DCTPP1 prevents a mutator phenotype through the modulation of dCTP, dTTP and dUTP pools. Cell. Mol. Life Sci. 2019, 77, 1645-1660. [CrossRef] [PubMed]

85. Hirano, M.; Carelli, V.; de Giorgio, R.; Pironi, L.; Accarino, A.; Cenacchi, G.; D’Alessandro, R.; Filosto, M.; Marti, R.; Nonino, F.; et al. Mitochondrial neurogastrointestinal encephalomyopathy (MNGIE): Position paper on diagnosis, prognosis, and treatment by the MNGIE International Network. J. Inherit. Metab. Dis. 2021, 44, 376-387. [CrossRef] [PubMed]

86. Ferraro, P.; Pontarin, G.; Crocco, L.; Fabris, S.; Reichard, P.; Bianchi, V. Mitochondrial deoxynucleotide pools in quiescent fibroblasts: A possible model for mitochondrial neurogastrointestinal encephalomyopathy (MNGIE). J. Biol. Chem. 2005, 280, 24472-24480. [CrossRef] [PubMed]

87. Vioque, E.G.; Torres-Torronteras, J.; Andreu, A.L.; Martí, R. Limited dCTP Availability Accounts for Mitochondrial DNA Depletion in Mitochondrial Neurogastrointestinal Encephalomyopathy (MNGIE). PLoS Genet. 2011, 7, e1002035. [CrossRef]

88. Pontarin, G.; Ferraro, P.; Valentino, M.L.; Hirano, M.; Reichard, P.; Bianchi, V. Mitochondrial DNA Depletion and Thymidine Phosphate Pool Dynamics in a Cellular Model of Mitochondrial Neurogastrointestinal Encephalomyopathy. J. Biol. Chem. 2006, 281, 22720-22728. [CrossRef]

89. Spinazzola, A.; Marti, R.; Nishino, I.; Andreu, A.L.; Naini, A.; Tadesse, S.; Pela, I.; Zammarchi, E.; Donati, M.A.; Oliver, J.A.; et al. Altered Thymidine Metabolism Due to Defects of Thymidine Phosphorylase. J. Biol. Chem. 2002, 277, 4128-4133. [CrossRef]

90. Lopez, L.C.; Akman, H.O.; García-Cazorla, Á.; Dorado, B.; Martí, R.; Nishino, I.; Tadesse, S.; Pizzorno, G.; Shungu, D.C.; Bonilla, E.; et al. Unbalanced deoxynucleotide pools cause mitochondrial DNA instability in thymidine phosphorylase-deficient mice. Hum. Mol. Genet. 2008, 18, 714-722. [CrossRef] [PubMed]

91. Nishigaki, Y.; Martiand, R.; Hirano, M. ND5 is a hot-spot for multiple atypical mitochondrial DNA deletions in mitochondrial neurogastrointestinal encephalomyopathy. Hum. Mol. Genet. 2003, 13, 91-101. [CrossRef]

92. Cámara, Y.; Vioque, E.G.; Scarpelli, M.; Torres-Torronteras, J.; Caballero, A.; Hirano, M.; Martí, R. Administration of deoxyribonucleosides or inhibition of their catabolism as a pharmacological approach for mitochondrial DNA depletion syndrome. Hum. Mol. Genet. 2014, 23, 2459-2467. [CrossRef]

93. Pastor-Anglada, M.; Perez-Torras, S. Nucleoside transporter proteins as biomarkers of drug responsiveness and drug targets. Front. Pharmacol. 2015, 6, 13. [CrossRef] 
94. Pastor-Anglada, M.; Urtasun, N.; Pérez-Torras, S. Intestinal Nucleoside Transporters: Function, Expression, and Regulation. Compr. Physiol. 2011, 8, 1003-1017. [CrossRef]

95. Lai, Y.; Tse, C.-M.; Unadkat, J.D. Mitochondrial Expression of the Human Equilibrative Nucleoside Transporter 1 (hENT1) Results in Enhanced Mitochondrial Toxicity of Antiviral Drugs. J. Biol. Chem. 2004, 279, 4490-4497. [CrossRef] [PubMed]

96. Morgan, N.V.; Morris, M.R.; Cangul, H.; Gleeson, D.; Straatman-Iwanowska, A.; Davies, N.; Keenan, S.; Pasha, S.; Rahman, F.; Gentle, D.; et al. Mutations in SLC29A3, Encoding an Equilibrative Nucleoside Transporter ENT3, Cause a Familial Histiocytosis Syndrome (Faisalabad Histiocytosis) and Familial Rosai-Dorfman Disease. PLoS Genet. 2010, 6, e1000833. [CrossRef] [PubMed]

97. Wevers, R.A.; Christensen, M.; Engelke, U.F.H.; Geuer, S.; Coene, K.; Kwast, J.T.; Lund, A.M.; Vissers, L.E.L.M. Functional disruption of pyrimidine nucleoside transporter CNT1 results in a novel inborn error of metabolism with high excretion of uridine and cytidine. J. Inherit. Metab. Dis. 2019, 42, 494-500. [CrossRef]

98. El-Hattab, A.W.; Suleiman, J.; Almannai, M.; Scaglia, F. Mitochondrial dynamics: Biological roles, molecular machinery, and related diseases. Mol. Genet. Metab. 2018, 125, 315-321. [CrossRef] [PubMed]

99. Yapa, N.M.; Lisnyak, V.; Reljic, B.; Ryan, M.T. Mitochondrial dynamics in health and disease. FEBS Lett. 2021, 595, 1184-1204. [CrossRef] [PubMed]

100. Elachouri, G.; Vidoni, S.; Zanna, C.; Pattyn, A.; Boukhaddaoui, H.; Gaget, K.; Yu-Wai-Man, P.; Gasparre, G.; Sarzi, E.; Delettre, C.; et al. OPA1 links human mitochondrial genome maintenance to mtDNA replication and distribution. Genome Res. 2010, 21, 12-20. [CrossRef] [PubMed]

101. Kimura, M.; Okano, Y. Human Misato regulates mitochondrial distribution and morphology. Exp. Cell Res. 2007, 313, 1393-1404. [CrossRef]

102. Kishita, Y.; Shimura, M.; Kohda, M.; Akita, M.; Imai-Okazaki, A.; Yatsuka, Y.; Nakajima, Y.; Ito, T.; Ohtake, A.; Murayama, K.; et al. A novel homozygous variant in MICOS13/QIL1 causes hepato-encephalopathy with mitochondrial DNA depletion syndrome. Mol. Genet. Genom. Med. 2020, 8, e1427. [CrossRef]

103. Martinelli, P.; La Mattina, V.; Bernacchia, A.; Magnoni, R.; Cerri, F.; Cox, G.; Quattrini, A.; Casari, G.; Rugarli, E.I. Genetic interaction between the $m$-AAA protease isoenzymes reveals novel roles in cerebellar degeneration. Hum. Mol. Genet. 2009, 18, 2001-2013. [CrossRef]

104. Baderna, V.; Schultz, J.; Kearns, L.S.; Fahey, M.; Thompson, B.A.; Ruddle, J.B.; Huq, A.; Maltecca, F. A novel AFG3L2 mutation close to AAA domain leads to aberrant OMA1 and OPA1 processing in a family with optic atrophy. Acta Neuropathol. Commun. 2020, 8, 93. [CrossRef]

105. Pfeffer, G.; Gorman, G.; Griffin, H.R.; Kurzawa-Akanbi, M.; Blakely, E.L.; Wilson, I.; Sitarz, K.; Moore, D.; Murphy, J.L.; Alston, C.; et al. Mutations in the SPG7 gene cause chronic progressive external ophthalmoplegia through disordered mitochondrial DNA maintenance. Brain 2014, 137, 1323-1336. [CrossRef]

106. El-Hattab, A.W.; Craigen, W.J.; Scaglia, F. Mitochondrial DNA maintenance defects. Biochim. Biophys. Acta BBA Mol. Basis Dis. 2017, 1863, 1539-1555. [CrossRef]

107. Haghighi, A.; Haack, T.B.; Atiq, M.; Mottaghi, H.; Haghighi-Kakhki, H.; Bashir, R.A.; Ahting, U.; Feichtinger, R.G.; Mayr, J.A.; Rötig, A.; et al. Sengers syndrome: Six novel AGK mutations in seven new families and review of the phenotypic and mutational spectrum of 29 patients. Orphanet J. Rare Dis. 2014, 9, 119. [CrossRef]

108. Epand, R.M.; Epand, R.F.; Berno, B.; Pelosi, L.; Brandolin, G. Association of Phosphatidic Acid with the Bovine Mitochondrial ADP / ATP Carrier. Biochemistry 2009, 48, 12358-12364. [CrossRef]

109. Kowluru, A.; Tannous, M.; Chen, H.Q. Localization and characterization of the mitochondrial isoform of the nucleoside diphosphate kinase in the pancreatic beta cell: Evidence for its complexation with mitochondrial succinyl-CoA synthetase. Arch. Bichem. Biophys. 2002, 398, 160-169. [CrossRef]

110. Blázquez-Bermejo, C.; Carreño-Gago, L.; Molina-Granada, D.; Aguirre, J.; Ramón, J.; Torres-Torronteras, J.; Cabrera-Pérez, R.; Martin, M.Á.; Domínguez-González, C.; Cruz, X.; et al. Increased dNTP pools rescue mtDNA depletion in human POLG-deficient fibroblasts. FASEB J. 2019, 33, 7168-7179. [CrossRef]

111. Dalla Rosa, I.; Camara, Y.; Durigon, R.; Moss, C.F.; Vidoni, S.; Akman, G.; Hunt, L.; Johnson, M.A.; Grocott, S.; Wang, L.; et al. MPV17 Loss Causes Deoxynucleotide Insufficiency and Slow DNA Replication in Mitochondrial. PLoS Genet. 2016, 12, e1005779. [CrossRef]

112. Blázquez-Bermejo, C.; Molina-Granada, D.; Vila-Julià, F.; Jiménez-Heis, D.; Zhou, X.; Torres-Torronteras, J.; Karlsson, A.; Martí, R.; Cámara, Y. Age-related metabolic changes limit efficacy of deoxynucleoside-based therapy in thymidine kinase 2-deficient mice. EBioMedicine 2019, 46, 342-355. [CrossRef]

113. Nambot, S.; Gavrilov, D.; Thevenon, J.; Bruel, A.; Bainbridge, M.; Rio, M.; Goizet, C.; Rotig, A.; Jaeken, J.; Niu, N.; et al. Further delineation of a rare recessive encephalomyopathy linked to mutations in GFER thanks to data sharing of whole exome sequencing data. Clin. Genet. 2017, 92, 188-198. [CrossRef]

114. Alsina, D.; Lytovchenko, O.; Schab, A.; Atanassov, I.; Schober, F.; Jiang, M.; Koolmeister, C.; Wedell, A.; Taylor, R.W.; Wredenberg, A.; et al. FBXL 4 deficiency increases mitochondrial removal by autophagy. EMBO Mol. Med. 2020, 12, 11659. [CrossRef]

115. Marchet, S.; Legati, A.; Nasca, A.; di Meo, I.; Spagnolo, M.; Zanetti, N.; Lamantea, E.; Catania, A.; Lamperti, C.; Ghezzi, D. Homozygous mutations in C1QBP as cause of progressive external ophthalmoplegia (PEO) and mitochondrial myopathy with multiple mtDNA deletions. Hum. Mutat. 2020, 41, 1745-1750. [CrossRef] 
116. Camp, K.M.; Krotoski, D.; Parisi, M.A.; Gwinn, K.A.; Cohen, B.H.; Cox, C.S.; Enns, G.M.; Falk, M.J.; Goldstein, A.C.; GopalSrivastava, R.; et al. Nutritional interventions in primary mitochondrial disorders: Developing an evidence base. Mol. Genet. Metab. 2016, 119, 187-206. [CrossRef]

117. Rahman, S. Pathophysiology of mitochondrial disease causing epilepsy and status epilepticus. Epilepsy Behav. 2015, 49, 71-75. [CrossRef]

118. Krahenbuhl, S.; Brandner, S.; Kleinle, S.; Liechti, S.; Straumann, D. Mitochondrial diseases represent a risk factor for valproateinduced fulminant liver failure. Liver Int. 2000, 20, 346-348. [CrossRef]

119. El-Hattab, A.W.; Scaglia, F. Mitochondrial DNA Depletion Syndromes: Review and Updates of Genetic Basis, Manifestations, and Therapeutic Options. Neurotherapeutics 2013, 10, 186-198. [CrossRef]

120. Kuszak, A.; Espey, M.G.; Falk, M.J.; Holmbeck, M.A.; Manfredi, G.; Shadel, G.S.; Vernon, H.J.; Zolkipli-Cunningham, Z. Nutritional Interventions for Mitochondrial OXPHOS Deficiencies: Mechanisms and Model Systems. Annu. Rev. Pathol. Mech. Dis. 2018, 13, 163-191. [CrossRef]

121. Santra, S.; Gilkerson, R.W.; Davidson, M.; Schon, E.A. Ketogenic treatment reduces deleted mitochondrial DNAs in cultured human cells. Ann. Neurol. 2004, 56, 662-669. [CrossRef]

122. Ahola-Erkkilä, S.; Carroll, C.J.; Peltola-Mjösund, K.; Tulkki, V.; Mattila, I.; Seppänen-Laakso, T.; Oresic, M.; Tyynismaa, H.; Suomalainen, A. Ketogenic diet slows down mitochondrial myopathy progression in mice. Hum. Mol. Genet. 2010, 19, 1974-1984. [CrossRef]

123. Kaji, S.; Murayama, K.; Nagata, I.; Nagasaka, H.; Takayanagi, M.; Ohtake, A.; Iwasa, H.; Nishiyama, M.; Okazaki, Y.; Harashima, H.; et al. Fluctuating liver functions in siblings with MPV17 mutations and possible improvement associated with dietary and pharmaceutical treatments targeting respiratory chain complex II. Mol. Genet. Metab. 2009, 97, 292-296. [CrossRef]

124. Hasselmann, O.; Blau, N.; Ramaekers, V.T.; Quadros, E.V.; Sequeira, J.; Weissert, M. Cerebral folate deficiency and CNS inflammatory markers in Alpers disease. Mol. Genet. Metab. 2010, 99, 58-61. [CrossRef] [PubMed]

125. Hirano, M.; Emmanuele, V.; Quinzii, C.M. Emerging therapies for mitochondrial diseases. Essays Biochem. 2018, 62, 467-481. [CrossRef] [PubMed]

126. Rodriguez, M.C.; Macdonald, J.R.; Mahoney, D.J.; Parise, G.; Beal, M.F.; Tarnopolsky, M.A. Beneficial effects of creatine, CoQ10, and lipoic acid in mitochondrial disorders. Muscle Nerve 2007, 35, 235-242. [CrossRef] [PubMed]

127. Tarnopolsky, M.A. Exercise as a Therapeutic Strategy for Primary Mitochondrial Cytopathies. J. Child. Neurol. 2014, 29, 1225-1234. [CrossRef] [PubMed]

128. Parikh, S.; Goldstein, A.; Koenig, M.K.; Scaglia, F.; Enns, G.M.; Saneto, R.; Anselm, I.; Cohen, B.H.; Falk, M.J.; Greene, C.; et al. Diagnosis and management of mitochondrial disease: A consensus statement from the Mitochondrial Medicine Society. Genet. Med. 2015, 17, 689-701. [CrossRef] [PubMed]

129. Fernandez-Marcos, P.J.; Auwerx, J. Regulation of PGC-1 $\alpha$, a nodal regulator of mitochondrial biogenesis. Am. J. Clin. Nutr. 2011, 93, 884S-890S. [CrossRef]

130. Johnson, S.C.; Yanos, M.E.; Kayser, E.-B.; Quintana, A.; Sangesland, M.; Castanza, A.; Uhde, L.; Hui, J.; Wall, V.Z.; Gagnidze, A.; et al. mTOR Inhibition Alleviates Mitochondrial Disease in a Mouse Model of Leigh Syndrome. Science 2013, 342, 1524-1528. [CrossRef]

131. Jain, I.H.; Zazzeron, L.; Goli, R.; Alexa, K.; Schatzman-Bone, S.; Dhillon, H.; Goldberger, O.; Peng, J.; Shalem, O.; Sanjana, N.E.; et al. Hypoxia as a therapy for mitochondrial disease. Science 2016, 352, 54-61. [CrossRef]

132. Rajendran, J.; Purhonen, J.; Tegelberg, S.; Smolander, O.; Mörgelin, M.; Rozman, J.; Gailus-Durner, V.; Fuchs, H.; de Angelis, M.H.; Auvinen, P.; et al. Alternative oxidase-mediated respiration prevents lethal mitochondrial cardiomyopathy. EMBO Mol. Med. 2019, 11, e9456. [CrossRef]

133. Siegmund, S.; Yang, H.; Sharma, R.; Javors, M.; Skinner, O.; Mootha, V.; Hirano, M.; Schon, E.A. Low-dose rapamycin extends lifespan in a mouse model of mtDNA depletion syndrome. Hum. Mol. Genet. 2017, 26, 4588-4605. [CrossRef]

134. Sharma, H.; Singh, D.; Mahant, A.; Sohal, S.K.; Kesavan, A.K. Samiksha Development of mitochondrial replacement therapy: A review. Heliyon 2020, 6, 04643. [CrossRef] [PubMed]

135. Jackson, C.B.; Turnbull, D.M.; Minczuk, M.; Gammage, P.A. Therapeutic Manipulation of mtDNA Heteroplasmy: A Shifting Perspective. Trends Mol. Med. 2020, 26, 698-709. [CrossRef] [PubMed]

136. Moraes, C.T.; Shanske, S.; Tritschler, H.J.; Aprille, J.R.; Andreetta, F.; Bonilla, E.; Schon, E.A.; DiMauro, S. mtDNA depletion with variable tissue expression: A novel genetic abnormality in mitochondrial diseases. Am. J. Hum. Genet. 1991, 48, $492-501$. [PubMed]

137. Zeviani, M.; Servidei, S.; Gellera, C.; Bertini, E.; DiMauro, S.; DiDonato, S. An autosomal dominant disorder with multiple deletions of mitochondrial DNA starting at the D-loop region. Nature 1989, 339, 309-311. [CrossRef]

138. Tiranti, V.; Viscomi, C.; Hildebrandt, T.; di Meo, I.; Mineri, R.; Tiveron, C.; Levitt, M.D.; Prelle, A.; Fagiolari, G.; Rimoldi, M.; et al. Loss of ETHE1, a mitochondrial dioxygenase, causes fatal sulfide toxicity in ethylmalonic encephalopathy. Nat. Med. 2009, 15, 200-205. [CrossRef]

139. Roeben, B.; Marquetand, J.; Bender, B.; Billing, H.; Haack, T.B.; Sanchez-Albisua, I.; Schols, L.; Blom, H.J.; Synofzik, M. Hemodialysis in MNGIE transiently reduces serum and urine levels of thymidine and deoxyuridine, but not CSF levels and neurological function. Orphanet J. Rare Dis. 2017, 12, 135. [CrossRef] 
140. Yavuz, H.; Özel, A.; Christensen, M.; Christensen, E.; Schwartz, M.; Elmaci, M.; Vissing, J. Treatment of Mitochondrial Neurogastrointestinal Encephalomyopathy with Dialysis. Arch. Neurol. 2007, 64, 435-438. [CrossRef] [PubMed]

141. Cabrera-Pérez, R.; Torres-Torronteras, J.; Vila-Julià, F.; Ortega, F.; Cámara, Y.; Barquinero, J.; Martí, R. Prospective therapeutic approaches in mitochondrial neurogastrointestinal encephalomyopathy (MNGIE). Expert Opin. Orphan Drugs 2015, 3, 1167-1182. [CrossRef]

142. Desgranges, C.; Razaka, G.; Rabaud, M.; Bricaud, H. Catabolism of thymidine in human blood platelets purification and properties of thymidine phosphorylase. Biochim. Biophys. Acta (BBA) Nucleic Acids Protein Synth. 1981, 654, 211-218. [CrossRef]

143. Yoshimura, A.; Kuwazuru, Y.; Furukawa, T.; Yoshida, H.; Yamada, K.; Akiyama, S.-I. Purification and tissue distribution of human thymidine phosphorylase; high expression in lymphocytes, reticulocytes and tumors. Biochim. Biophys. Acta (BBA) Gen. Subj. 1990, 1034, 107-113. [CrossRef]

144. Cass, C.E.; Young, J.D.; Baldwin, S.A.; Cabrita, M.A.; Graham, K.A.; Griffiths, M.; Jennings, L.L.; Mackey, J.R.; Ng, A.M.L.; Ritzel, M.W.L.; et al. Nucleoside Transporters of Mammalian Cells. Membr. Transp. Drug Targets 1999, 12, 313-352. [CrossRef]

145. De Vocht, C.; Ranquin, A.; van Ginderachter, J.; Vanhaecke, T.; Rogiers, V.; van Gelder, P.; Versées, W.; Steyaert, J. Polymeric nanoreactors for enzyme replacement therapy of MNGIE. J. Control. Release 2010, 148, e19-e20. [CrossRef]

146. De Vocht, C.; Ranquin, A.; Willaert, R.; van Ginderachter, J.A.; Vanhaecke, T.; Rogiers, V.; Versées, W.; van Gelder, P.; Steyaert, J. Assessment of stability, toxicity and immunogenicity of new polymeric nanoreactors for use in enzyme replacement therapy of MNGIE. J. Control. Release 2009, 137, 246-254. [CrossRef] [PubMed]

147. Moran, N.F.; Bain, M.D.; Muqit, M.; Bax, B.E. Carrier erythrocyte entrapped thymidine phosphorylase therapy for MNGIE. Neurology 2008, 71, 686-688. [CrossRef]

148. Levene, M.; Coleman, D.G.; Kilpatrick, H.C.; Fairbanks, L.D.; Gangadharan, B.; Gasson, C.; Bax, B.E. Pre-clinical toxicity evaluation of erythrocyte-encapsulated thymidine phosphorylase in BALB/c mice and beagle dogs: An enzyme-replacement therapy for mitochondrial neurogastrointestinal encephalomyopathy. Toxicol. Sci. 2013, 131, 311-324. [CrossRef]

149. Bax, B.E.; Bain, M.D.; Scarpelli, M.; Filosto, M.; Tonin, P.; Moran, N. Clinical and biochemical improvements in a patient with MNGIE following enzyme replacement. Neurology 2013, 81, 1269-1271. [CrossRef] [PubMed]

150. Levene, M.; Bain, M.D.; Moran, N.F.; Nirmalananthan, N.; Poulton, J.; Scarpelli, M.; Filosto, M.; Mandel, H.; MacKinnon, A.D.; Fairbanks, L.; et al. Safety and Efficacy of Erythrocyte Encapsulated Thymidine Phosphorylase in Mitochondrial Neurogastrointestinal Encephalomyopathy. J. Clin. Med. 2019, 8, 457. [CrossRef]

151. Bax, B.E.; Levene, M.; Bain, M.D.; Fairbanks, L.D.; Filosto, M.; Uçar, S.K.; Klopstock, T.; Kornblum, C.; Mandel, H.; Rahman, S.; et al. Erythrocyte Encapsulated Thymidine Phosphorylase for the Treatment of Patients with Mitochondrial Neurogastrointestinal Encephalomyopathy: Study Protocol for a Multi-Centre, Multiple Dose, Open Label Trial. J. Clin. Med. 2019, 8, 1096. [CrossRef]

152. Lara, M.C.; Weiss, B.; Illa, I.; Madoz, P.; Massuet, L.; Andreu, A.L.; Valentino, M.L.; Anikster, Y.; Hirano, M.; Marti, R. Infusion of platelets transiently reduces nucleoside overload in MNGIE. Neurology 2006, 67, 1461-1463. [CrossRef]

153. Hussein, E. Non-myeloablative bone marrow transplant and platelet infusion can transiently improve the clinical outcome of mitochondrial neurogastrointestinal encephalopathy: A case report. Transfus. Apher. Sci. 2013, 49, 208-211. [CrossRef] [PubMed]

154. Hirano, M.; Marti, R.; Casali, C.; Tadesse, S.; Uldrick, T.; Fine, B.; Escolar, D.M.; Valentino, M.L.; Nishino, I.; Hesdorffer, C.; et al. Allogeneic stem cell transplantation corrects biochemical derangements in MNGIE. Neurology 2006, 67, 1458-1460. [CrossRef]

155. Halter, J.; Schüpbach, W.M.M.; Casali, C.; Elhasid, R.; Fay, K.; Hammans, S.; Illa, I.; Kappeler, L.; Krähenbühl, S.; Lehmann, T.; et al. Allogeneic hematopoietic SCT as treatment option for patients with mitochondrial neurogastrointestinal encephalomyopathy (MNGIE): A consensus conference proposal for a standardized approach. Bone Marrow Transplant. 2010, 46, 330-337. [CrossRef]

156. Halter, J.P.; Michael, W.; Schupbach, M.; Mandel, H.; Casali, C.; Orchard, K.; Collin, M.; Valcarcel, D.; Rovelli, A.; Filosto, M.; et al. Allogeneic haematopoietic stem cell transplantation for mitochondrial neurogastrointestinal encephalomyopathy. Brain 2015, 138, 2847-2858. [CrossRef] [PubMed]

157. Filosto, M.; Scarpelli, M.; Tonin, P.; Lucchini, G.; Pavan, F.; Santus, F.; Parini, R.; Donati, M.A.; Cotelli, M.S.; Vielmi, V.; et al. Course and management of allogeneic stem cell transplantation in patients with mitochondrial neurogastrointestinal encephalomyopathy. J. Neurol. 2012, 259, 2699-2706. [CrossRef] [PubMed]

158. Parikh, S.; Karaa, A.; Goldstein, A.; Ng, Y.S.; Gorman, G.; Feigenbaum, A.; Christodoulou, J.; Haas, R.; Tarnopolsky, M.; Cohen, B.K.; et al. Solid organ transplantation in primary mitochondrial disease: Proceed with caution. Mol. Genet. Metab. 2016, 118, 178-184. [CrossRef]

159. El-Hattab, A.W.; Wang, J.; Dai, H.; Almannai, M.; Scaglia, F.; Craigen, W.J.; Wong, L.J.C. MPV17-related mitochondrial DNA maintenance defect. In GeneReviews ${ }^{\circledR}$; Adam, M.P., Ardinger, H.H., Pagon, R.A., Wallace, S.E., Bean, L.J.H., Stephens, K., Amemiya, A., Eds.; University of Washington: Seattle, WA, USA, 1993.

160. Shimura, M.; Kuranobu, N.; Ogawa-Tominaga, M.; Akiyama, N.; Sugiyama, Y.; Ebihara, T.; Fushimi, T.; Ichimoto, K.; Matsunaga, A.; Tsuruoka, T.; et al. Clinical and molecular basis of hepatocerebral mitochondrial DNA depletion syndrome in Japan: Evaluation of outcomes after liver transplantation. Orphanet J. Rare Dis. 2020, 15, 169. [CrossRef]

161. El-Hattab, A.W.; Zarante, A.M.; Almannai, M.; Scaglia, F. Therapies for mitochondrial diseases and current clinical trials. Mol. Genet. Metab. 2017, 122, 1-9. [CrossRef]

162. Kelly, D.A. Liver transplantation: To do or not to do? Pediatr. Transplant. 2000, 4, 170-172. [CrossRef]

163. Tzoulis, C.; Engelsen, B.A.; Telstad, W.; Aasly, J.; Zeviani, M.; Winterthun, S.; Ferrari, G.; Aarseth, J.H.; Bindoff, L.A. The spectrum of clinical disease caused by the A467T and W748S POLG mutations: A study of 26 cases. Brain 2006, 129, 1685-1692. [CrossRef] 
164. Wong, L.-J.; Naviaux, R.K.; Brunetti-Pierri, N.; Zhang, Q.; Schmitt, E.S.; Truong, C.; Milone, M.; Cohen, B.H.; Wical, B.; Ganesh, J.; et al. Molecular and clinical genetics of mitochondrial diseases due to POLG mutations. Hum. Mutat. 2008, 29, E150-E172. [CrossRef] [PubMed]

165. Boschetti, E.; D’Alessandro, R.; Bianco, F.; Carelli, V.; Cenacchi, G.; Pinna, A.D.; Del Gaudio, M.; Rinaldi, R.; Stanghellini, V.; Pironi, L.; et al. Liver as a Source for Thymidine Phosphorylase Replacement in Mitochondrial Neurogastrointestinal Encephalomyopathy. PLoS ONE 2014, 9, e96692. [CrossRef] [PubMed]

166. D’Angelo, R.; Boschetti, E.; Amore, G.; Costa, R.; Pugliese, A.; Caporali, L.; Gramegna, L.L.; Papa, V.; Vizioli, L.; Capristo, M.; et al. Liver transplantation in mitochondrial neurogastrointestinal encephalomyopathy (MNGIE): Clinical long-term follow-up and pathogenic implications. J. Neurol. 2020, 267, 3702-3710. [CrossRef]

167. D'Angelo, R.; Rinaldi, R.; Pironi, L.; Dotti, M.T.; Pinna, A.D.; Boschetti, E.; Capristo, M.; Mohamed, S.; Contin, M.; Caporali, L.; et al. Liver transplant reverses biochemical imbalance in mitochondrial neurogastrointestinal encephalomyopathy. Mitochondrion 2017, 34, 101-102. [CrossRef]

168. De Giorgio, R.; Pironi, L.; Rinaldi, R.; Boschetti, E.; Caporali, L.; Capristo, M.; Casali, C.; Cenacchi, G.; Contin, M.; D’Angelo, R.; et al. Liver transplantation for mitochondrial neurogastrointestinal encephalomyopathy. Ann. Neurol. 2016, 80, 448-455. [CrossRef]

169. Kripps, K.; Nakayuenyongsuk, W.; Shayota, B.J.; Berquist, W.; Gomez-Ospina, N.; Esquivel, C.O.; Concepcion, W.; Sampson, J.B.; Cristin, D.J.; Jackson, W.E.; et al. Successful liver transplantation in mitochondrial neurogastrointestinal encephalomyopathy (MNGIE). Mol. Genet. Metab. 2020, 130, 58-64. [CrossRef]

170. Taanman, J.-W.; Muddle, J.R.; Muntau, A.C. Mitochondrial DNA depletion can be prevented by dGMP and dAMP supplementation in a resting culture of deoxyguanosine kinase-deficient fibroblasts. Hum. Mol. Genet. 2003, 12, 1839-1845. [CrossRef]

171. Akman, H.O.; Dorado, B.; Lopez, L.C.; García-Cazorla, Á.; Vilà, M.R.; Tanabe, L.M.; Dauer, W.T.; Bonilla, E.; Tanji, K.; Hirano, M. Thymidine kinase $2(\mathrm{H} 126 \mathrm{~N})$ knockin mice show the essential role of balanced deoxynucleotide pools for mitochondrial DNA maintenance. Hum. Mol. Genet. 2008, 17, 2433-2440. [CrossRef]

172. Domínguez-González, C.; Hernández-Laín, A.; Rivas, E.; Hernández-Voth, A.; Catalán, J.S.; Fernandez-Torron, R.; Fuiza-Luces, C.; García, J.G.; Morís, G.; Olivé, M.; et al. Late-onset thymidine kinase 2 deficiency: A review of 18 cases. Orphanet J. Rare Dis. 2019, 14, 1-10. [CrossRef]

173. Camara, Y.; Carreño-Gago, L.; Martín, M.A.; Melia, M.J.; Blázquez, A.; Delmiro, A.; Garrabou, G.; Morén, C.; Díaz-Manera, J.; Gallardo, E.; et al. Severe TK2 enzyme activity deficiency in patients with mild forms of myopathy. Neurology 2015, 84, 2286-2288. [CrossRef]

174. Garone, C.; Garcia-Diaz, B.; Emmanuele, V.; Lopez, L.C.; Tadesse, S.; Akman, H.O.; Tanji, K.; Quinzii, C.M.; Hirano, M. Deoxypyrimidine monophosphate bypass therapy for thymidine kinase 2 deficiency. EMBO Mol. Med. 2014, 6, 1016-1027. [CrossRef]

175. Lopez-Gomez, C.; Levy, R.J.; Sanchez-Quintero, M.J.; Juanola-Falgarona, M.; Barca, E.; Garcia-Diaz, B.; Tadesse, S.; Garone, C.; Hirano, M. Deoxycytidine and Deoxythymidine Treatment for Thymidine Kinase 2 Deficiency. Ann. Neurol. 2017, 81, 641-652. [CrossRef]

176. Zhou, X.; Solaroli, N.; Bjerke, M.; Stewart, J.B.; Rozell, B.; Johansson, M.; Karlsson, A. Progressive loss of mitochondrial DNA in thymidine kinase 2-deficient mice. Hum. Mol. Genet. 2008, 17, 2329-2335. [CrossRef]

177. Lopez-Gomez, C.; Hewan, H.; Sierra, C.; Akman, H.O.; Sanchez-Quintero, M.J.; Juanola-Falgarona, M.; Tadesse, S.; Tanji, K.; Konofagou, E.E.; Hirano, M. Bioavailability and cytosolic kinases modulate response to deoxynucleoside therapy in TK2 deficiency. EBioMedicine 2019, 46, 356-367. [CrossRef]

178. Domínguez-González, C.; Madruga-Garrido, M.; Mavillard, F.; Garone, C.; Aguirre-Rodríguez, F.J.; Donati, M.A.; Kleinsteuber, K.; Martí, I.; Martín-Hernández, E.; Morealejo-Aycinena, J.P.; et al. Deoxynucleoside Therapy for Thymidine Kinase 2-Deficient Myopathy. Ann. Neurol. 2019, 86, 293-303. [CrossRef]

179. Hernandez-Voth, A.; Catalan, J.S.; Blanco, M.C.; Mendez, A.C.; Martin, M.A.; de la Hoz, C.D.F.F.; Garrido, V.V.; DominguezGonzalez, C. Deoxynucleoside therapy for respiratory involvement in adult patients with thymidine kinase 2-deficient myopathy. BMJ Open Respir. Res. 2020, 7, e000774. [CrossRef]

180. Dominguez-Gonzalez, C.; Badosa, C.; Madruga-Garrido, M.; Marti, I.; Paradas, C.; Ortez, C.; Diaz-Manera, J.; Berardo, A.; Alonso-Perez, J.; Trifunov, S.; et al. Growth Differentiation Factor 15 is a potential biomarker of therapeutic response for TK2 deficient myopathy. Sci. Rep. 2020, 10, 10111. [CrossRef]

181. Bulst, S.; Holinski-Feder, E.; Payne, B.; Abicht, A.; Krause, S.; Lochmüller, H.; Chinnery, P.F.; Walter, M.C.; Horvath, R. In vitro supplementation with deoxynucleoside monophosphates rescues mitochondrial DNA depletion. Mol. Genet. Metab. 2012, 107, 95-103. [CrossRef]

182. Pontarin, G.; Ferraro, P.; Bee, L.; Reichard, P.; Bianchi, V. Mammalian ribonucleotide reductase subunit p53R2 is required for mitochondrial DNA replication and DNA repair in quiescent cells. Proc. Natl. Acad. Sci. USA 2012, 109, 13302-13307. [CrossRef]

183. Trifunovic, A.; Wredenberg, A.; Falkenberg, M.; Spelbrink, J.N.; Rovio, A.T.; Bruder, C.E.; Bohlooly-Y, M.; Gidlöf, S.; Oldfors, A.; Wibom, R.; et al. Premature ageing in mice expressing defective mitochondrial DNA polymerase. Nature 2004, 429, 417-423. [CrossRef] 
184. Silva-Pinheiro, P.; Pardo-Hernández, C.; Reyes, A.; Tilokani, L.; Mishra, A.; Cerutti, R.; Li, S.; Rozsivalova, D.-H.; Valenzuela, S.; Dogan, S.A.; et al. DNA polymerase gamma mutations that impair holoenzyme stability cause catalytic subunit depletion. Nucleic Acids Res. 2021, 49, 5230-5248. [CrossRef] [PubMed]

185. Mingozzi, F.; High, K.A. Therapeutic in vivo gene transfer for genetic disease using AAV: Progress and challenges. Nat. Rev. Genet. 2011, 12, 341-355. [CrossRef] [PubMed]

186. Flierl, A.; Chen, Y.; Coskun, P.E.; Samulski, R.J.; Wallace, D.C. Adeno-associated virus-mediated gene transfer of the heart/muscle adenine nucleotide translocator (ANT) in mouse. Gene Ther. 2005, 12, 570-578. [CrossRef] [PubMed]

187. Viscomi, C.; Spinazzola, A.; Maggioni, M.; Fernandez-Vizarra, E.; Massa, V.; Pagano, C.; Vettor, R.; Mora, M.; Zeviani, M. Early-onset liver mtDNA depletion and late-onset proteinuric nephropathy in Mpv17 knockout mice. Hum. Mol. Genet. 2008, 18, 12-26. [CrossRef]

188. Bottani, E.; Giordano, C.; Civiletto, G.; di Meo, I.; Auricchio, A.; Ciusani, E.; Marchet, S.; Lamperti, C.; D’ Amati, G.; Viscomi, C.; et al. AAV-mediated Liver-specific MPV17 Expression Restores mtDNA Levels and Prevents Diet-induced Liver Failure. Mol. Ther. 2014, 22, 10-17. [CrossRef]

189. Torres-Torronteras, J.; Gomez, A.; Eixarch, H.; Palenzuela, L.; Pizzorno, G.; Hirano, M.; Andreu, A.L.; Barquinero, J.; Marti, R. Hematopoietic gene therapy restores thymidine phosphorylase activity in a cell culture and a murine model of MNGIE. Gene Ther. 2011, 18, 795-806. [CrossRef]

190. Torres-Torronteras, J.; Cabrera-Perez, R.; Barba, I.; Costa, C.; de Luna, N.; Andreu, A.L.; Barquinero, J.; Hirano, M.; Camara, Y.; Marti, R. Long-Term Restoration of Thymidine Phosphorylase Function and Nucleoside Homeostasis Using Hematopoietic Gene Therapy in a Murine Model of Mitochondrial Neurogastrointestinal Encephalomyopathy. Hum. Gene Ther. 2016, $27,656-667$. [CrossRef]

191. Yadak, R.; Cabrera-Pérez, R.; Torres-Torronteras, J.; Bugiani, M.; Haeck, J.C.; Huston, M.W.; Bogaerts, E.; Goffart, S.; Jacobs, E.H.; Stok, M.; et al. Preclinical Efficacy and Safety Evaluation of Hematopoietic Stem Cell Gene Therapy in a Mouse Model of MNGIE. Mol. Ther. Methods Clin. Dev. 2018, 8, 152-165. [CrossRef]

192. Torres-Torronteras, J.; Cabrera-Perez, R.; Vila-Julia, F.; Viscomi, C.; Camara, Y.; Hirano, M.; Zeviani, M.; Marti, R. Long-Term Sustained Effect of Liver-Targeted Adeno-Associated Virus Gene Therapy for Mitochondrial Neurogastrointestinal Encephalomyopathy. Hum. Gene Ther. 2018, 29, 708-718. [CrossRef]

193. Torres-Torronteras, J.; Viscomi, C.; Cabrera-Pérez, R.; Cámara, Y.; di Meo, I.; Barquinero, J.; Auricchio, A.; Pizzorno, G.; Hirano, M.; Zeviani, M.; et al. Gene Therapy Using a Liver-targeted AAV Vector Restores Nucleoside and Nucleotide Homeostasis in a Murine Model of MNGIE. Mol. Ther. 2014, 22, 901-907. [CrossRef]

194. Cabrera-Perez, R.; Vila-Julia, F.; Hirano, M.; Mingozzi, F.; Torres-Torronteras, J.; Marti, R. The alpha-1-antitrypsin promoter improves the efficacy of an AAV vector for the treatment of MNGIE. Hum. Gene Ther. 2019, 30, 985-998. [CrossRef] [PubMed]

195. Vila-Julià, F.; Cabrera-Pérez, R.; Cámara, Y.; Molina-Berenguer, M.; Lope-Piedrafita, S.; Hirano, M.; Mingozzi, F.; TorresTorronteras, J.; Martí, R. Efficacy of adeno-associated virus gene therapy in a MNGIE murine model enhanced by chronic exposure to nucleosides. EBioMedicine 2020, 62, 103133. [CrossRef] [PubMed]

196. Jiang, H.; Couto, L.B.; Patarroyo-White, S.; Liu, T.; Nagy, D.; Vargas, J.A.; Zhou, S.; Scallan, C.D.; Sommer, J.; Vijay, S.; et al. Effects of transient immunosuppression on adenoassociated, virus-mediated, liver-directed gene transfer in rhesus macaques and implications for human gene therapy. Blood 2006, 108, 3321-3328. [CrossRef]

197. Nathwani, A.C.; Gray, J.T.; Ng, C.Y.C.; Zhou, J.; Spence, Y.; Waddington, S.N.; Tuddenham, E.G.D.; Kemball-Cook, G.; McIntosh, J.; Boon-Spijker, M.; et al. Self-complementary adeno-associated virus vectors containing a novel liver-specific human factor IX expression cassette enable highly efficient transduction of murine and nonhuman primate liver. Blood 2006, 107, $2653-2661$. [CrossRef]

198. Vercauteren, K.; Hoffman, B.E.; Zolotukhin, I.; Keeler, G.D.; Xiao, J.W.; Basner-Tschakarjan, E.; High, K.; Ertl, H.C.; Rice, C.M.; Srivastava, A.; et al. Superior In Vivo Transduction of Human Hepatocytes Using Engineered AAV3 Capsid. Mol. Ther. 2016, 24, 1042-1049. [CrossRef]

199. Civiletto, G.; Varanita, T.; Cerutti, R.; Gorletta, T.; Barbaro, S.; Marchet, S.; Lamperti, C.; Viscomi, C.; Scorrano, L.; Zeviani, M. Opa1 Overexpression Ameliorates the Phenotype of Two Mitochondrial Disease Mouse Models. Cell Metab. 2015, 21, 845-854. [CrossRef]

200. Korwitz, A.; Merkwirth, C.; Richter-Dennerlein, R.; Troeder, S.E.; Sprenger, H.-G.; Quiros, P.M.; López-Otín, C.; Rugarli, E.; Langer, T. Loss of OMA1 delays neurodegeneration by preventing stress-induced OPA1 processing in mitochondria. J. Cell Biol. 2016, 212, 157-166. [CrossRef]

201. Rocha, A.G.; Franco, A.; Krezel, A.M.; Rumsey, J.M.; Alberti, J.M.; Knight, W.C.; Biris, N.; Zacharioudakis, E.; Janetka, J.W.; Baloh, R.H.; et al. MFN2 agonists reverse mitochondrial defects in preclinical models of Charcot-Marie-Tooth disease type 2A. Science 2018, 360, 336-341. [CrossRef]

202. Karaa, A.; Haas, R.; Goldstein, A.; Vockley, J.; Weaver, W.D.; Cohen, B.H. Randomized dose-escalation trial of elamipretide in adults with primary mitochondrial myopathy. Neurology 2018, 90, e1212-e1221. [CrossRef]

203. Szeto, H.H.; Birk, A.V. Serendipity and the Discovery of Novel Compounds That Restore Mitochondrial Plasticity. Clin. Pharmacol. Ther. 2014, 96, 672-683. [CrossRef] 
204. Pitayu, L.; Baruffini, E.; Rodier, C.; Rotig, A.; Lodi, T.; Delahodde, A. Combined use of Saccharomyces cerevisiae, Caenorhabditis elegans and patient fibroblasts leads to the identification of clofilium tosylate as a potential therapeutic chemical against POLGrelated diseases. Hum. Mol. Genet. 2016, 25, 715-727. [CrossRef]

205. Facchinello, N.; Laquatra, C.; Locatello, L.; Beffagna, G.; Branas Casas, R.; Fornetto, C.; Dinarello, A.; Martorano, L.; Vettori, A.; Risato, G.; et al. Efficient clofilium tosylate-mediated rescue of POLG-related disease phenotypes in zebrafish. Cell Death Dis. 2021, 12, 100. [CrossRef]

206. Munro, B.; Horvath, R.; Muller, J.S. Nucleoside supplementation modulates mitochondrial DNA copy number in the dguok - /zebrafish. Hum. Mol. Genet. 2019, 28, 796-803. [CrossRef]

207. Ruzzenente, B.; Rötig, A.; Metodiev, M.D. Mouse models for mitochondrial diseases. Hum. Mol. Genet. 2016, 25, R115-R122. [CrossRef]

208. Tyynismaa, H.; Suomalainen, A. Mouse models of mtDNA replication diseases. Methods 2010, 51, 405-410. [CrossRef]

209. Rahn, J.J.; Bestman, J.E.; Stackley, K.D.; Chan, S.S. Zebrafish lacking functional DNA polymerase gamma survive to juvenile stage, despite rapid and sustained mitochondrial DNA depletion, altered energetics and growth. Nucleic Acids Res. 2015, 43, 10338-10352. [CrossRef]

210. Kimura, T.; Takeda, S.; Sagiya, Y.; Gotoh, M.; Nakamura, Y.; Arakawa, H. Impaired function of p53R2 in Rrm2b-null mice causes severe renal failure through attenuation of dNTP pools. Nat. Genet. 2003, 34, 440-445. [CrossRef]

211. Tyynismaa, H.; Mjosund, K.P.; Wanrooij, S.; Lappalainen, I.; Ylikallio, E.; Jalanko, A.; Spelbrink, J.N.; Paetau, A.; SuomalainenWartiovaara, A. Mutant mitochondrial helicase Twinkle causes multiple mtDNA deletions and a late-onset mitochondrial disease in mice. Proc. Natl. Acad. Sci. USA 2005, 102, 17687-17692. [CrossRef]

212. Zhou, X.; Curbo, S.; Zhao, Q.; Krishnan, S.; Kuiper, R.; Karlsson, A. Severe mtDNA depletion and dependency on catabolic lipid metabolism in DGUOK knockout mice. Hum. Mol. Genet. 2019, 28, 2874-2884. [CrossRef] [PubMed]

213. Garcia-Diaz, B.; Garone, C.; Barca, E.; Mojahed, H.; Gutierrez, P.; Pizzorno, G.; Tanji, K.; Arias-Mendoza, F.; Quinzii, C.M.; Hirano, M. Deoxynucleoside stress exacerbates the phenotype of a mouse model of mitochondrial neurogastrointestinal encephalopathy. Brain 2014, 137, 1337-1349. [CrossRef] [PubMed]

214. Darin, N.; Oldfors, A.; Moslemi, A.R.; Holme, E.; Tulinius, M. The incidence of mitochondrial encephalomyopathies in childhood: Clinical features and morphological, biochemical, and DNA abnormalities. Ann. Neurol. 2001, 49, 377-383. [CrossRef] [PubMed]

215. D'Angelo, R.; Rinaldi, R.; Carelli, V.; Boschetti, E.; Caporali, L.; Capristo, M.; Casali, C.; Cenacchi, G.; Gramegna, L.L.; Lodi, R.; et al. ITA-MNGIE: An Italian regional and national survey for mitochondrial neuro-gastro-intestinal encephalomyopathy. Neurol. Sci. 2016, 37, 1149-1151. [CrossRef] [PubMed] 